\title{
Studi Kasus Asuhan Keperawatan Psikososial Dengan Masalah Harga Diri Rendah Situasional Pada Penderita Tb Paru
}

\section{Fahrini Syafitri}

\author{
Fahrinisyafitri02@gmail.com
}

\section{BAB I \\ PENDAHULUAN}

\subsection{Latar Belakang}

Tuberkulosis (TB) paru merupakan penyakit infeksi menular kronik yang disebabkan oleh kuman Mycobacterium tuberculosis. Penyakit ini masih menjadi masalah kesehatan global menduduki urutan kedua setelah Human Imunodeficiency Virus (HIV) sebagai penyakit infeksi yang menyebabkan kematian terbanyak pada penduduk dunia. Penyakit ini dapat diderita oleh setiap orang, tetapi paling sering ditemukan pada usia muda atau usia produktif yaitu 15-50 tahun. Penyakit ini sering ditemukan pada yang bertubuh lemah, kurang gizi, atau yang tinggal satu rumah dan berdesak - desakkan bersama penderita TB Paru (Suryani \& Efendi, 2020)

Sepertiga dari jumlah penduduk di dunia sudah tertular dengan tuberkulosis (TB) di mana sebagian besar penderita TB terjadi pada usia produktif 15-55 tahun. Menurut data dan informasi profil kesehatan Indonesia. Menurut jenis kelamin, jumlah kasus pada laki-laki lebih tinggi daripada perempuan yaitu 270 kasus pada laki-laki dan 187 kasus pada perempuan. Menurut kelompok umur, kasus tuberculosis pada tahun 2016 paling banyak ditemukan pada kelompok umur 25 - 34 tahun. Sedangkan kasus tuberculosis pada anak - anak 0 - 14 tahun sekitar $3 \%$ dari total penemuan kasus (Kenedyanti \& Sulistyorini, 2017)

Data yang didapat sejak tahun 2003 hingga saat ini diperkirakan masih terdapat sekitar 9,5 juta kasus baru tuberkulosis dan sekitar 0,5 juta orang meninggal akibat 
tuberkulosis di seluruh dunia. Kondisi ini membuat WHO masih menyatakan TBC sebagai kedaruratan global bagi kemanusiaan di seluruh dunia sehingga langkahlangkah penatalaksanaan untuk mengendalikan penyakit ini terus dilakukan (Kemenkes RI, 2018)

Penyakit tuberkulosis merupakan salah satu masalah kesehatan yang juga dipandang cukup penting di Indonesia. Pada tahun 2018 jumlah penderita TBC di Indonesia menduduki peringkat ke-3 negara dengan jumlah penderita TBC terbanyak di dunia setelah India dan China. Pada tahun 2020 peringkat ini telah menurun menjadi nomer 5 setelah India, Cina, Afrika Selatan, dan Nigeria. Jumlah penderita TBC di Indonesia saat ini adalah sekitar 5,8 \% dari total jumlah pasien TBC dunia dan diperkirakan masih terdapat 528.000 kasus TBC baru dengan kematian sekitar 91.000 orang per tahun dan sebanyak $70 \%$ dari angka itu terjadi pada usia produktif (Kemenkes RI, 2020).

Penyakit tuberkulosis merupakan salah satu masalah kesehatan yang juga dipandang cukup penting di Indonesia. Pada tahun 2006 jumlah penderita TBC di Indonesia menduduki peringkat ke-3 negara dengan jumlah penderita TBC terbanyak di dunia setelah India dan China. Pada tahun 2009 peringkat ini telah menurun menjadi nomer 5 setelah India, Cina, Afrika Selatan, dan Nigeria. Jumlah penderita TBC di Indonesia saat ini adalah sekitar 5,8 \% dari total jumlah pasien TBC dunia dan diperkirakan masih terdapat 528.000 kasus TBC baru dengan kematian sekitar 91.000 orang per tahun dan sebanyak 70\% dari angka itu terjadi pada usia produktif (suprapto, 2018)

Data yang diperoleh dari Dinas Kesehatan sumut penderita TB di Sumut tahun 2019 tercatat 37.865 orang. Ke depan, jumlah tersebut diharapkan dapat terus ditekan seiring upaya pemerintah untuk mencapai eliminasi TB tahun 2030 sedangkan jumlah kasus baru sebanyak 2.054 kasus. Kebutuhan pokok manusia adalah tempat tinggal (rumah), serta kebutuhan sandang dan pangan. Rumah adalah pengembangan kehidupan dan tempat untuk berkumpul semua anggota keluarga untuk beraktivitas dan menghabiskan sebagian besar waktunya. Konstruksi rumah serta keadaan 
lingkungan tempat tinggal yang tidak sesuai dan tidak memenuhi syarat kesehatan merupakan faktor risiko terjadinya penularan berbagai macam penyakit. Kriteria rumah sehat antara lain memenuhi kebutuhan fisiologis yaitu penghawaan, pencahayaan, dan memiliki ruang gerak yang cukup untuk semua anggota keluarga, serta terhindar dari kebisingan yang mengganggu (Kenedyanti \& Sulistyorini, 2017).

Dalam hal kondisi faktor penyebab dari gangguan harga diri yang pertama yaitu faktor predisposisi meliputi faktor yang mempengaruhi harga diri seperti penolakan dari orang tua, harapan dan ideal diri yang tidak bisa tercapai, selalu menemui kegagalan, tanggung jawab personal yang kurang serta ketergantungan terhadap orang lain, faktor performa peran seperti peran gender, tuntutan kerja dan budaya yang dapat mempengaruhi, sedangkan faktor identitas diri meliputi tekanan yang disebabkan dari orang - orang terdekat seperti orang tua yang kurang percaya akan dirinya, tekanan dari kelompok sebaya dan perubahan struktur sosial, yang kedua yaitu faktor stresr pencetus dapat terjadi diakibatkan oleh truma seperti pskosial atau ancaman yang dapat mengganggu kehidupan, ketegangan peran yang mengakibatkan individu frustasi atas posisi yang didapatkan. Dengan gangguan harga diri, seseorang akan menghadapi suasana hati dan ingatan tentang masa lalu yang negatif dan lebih rentan mengalami depresi ketika menghadapi stress karena pola pikir yang buruk tentang masa lalu yang negatif dan lebih rentan mengalami depresi ketika menghadapi stress karena pola pikir yang buruk tentang diri sendiri, tujuan hidup yang tidak jelas, dan masa depan yang lebih pesimis, semakin rendah harga diri seseorang akan lebih berisiko terkena gangguan kepribadian (Pardede, 2017)

Adapun faktor penyebab dari gangguan harga diri yang pertama yaitu faktor predisposisi meliputi faktor yang mempengaruhi harga diri seperti penolakan dari orang tua, harapan dan ideal diri yang tidak bisa tercapai, selalu menemui kegagalan, tanggung jawab personal yang kurang serta ketergantungan terhadap orang lain, faktor performa peran seperti peran gender, tuntutan kerja dan budaya yang dapat mempengaruhi, sedangkan faktor identitas diri meliputi tekanan yang disebabkan dari orang - orang terdekat seperti orang tua yang kurang percaya akan dirinya, tekanan 
dari kelompok sebaya dan perubahan struktur sosial, yang kedua yaitu faktor stresr pencetus dapat terjadi diakibatkan oleh truma seperti penganiyaan seksual dan pskosial atau ancaman yang dapat mengganggu kehidupan, ketegangan peran yang mengakibatkan individu frustasi atas posisi yang didapatkan. Dengan gangguan harga diri, seseorang akan menghadapi suasana hati dan ingatan tentang masa lalu yang negatif dan lebih rentan mengalami depresi ketika menghadapi stress karena pola pikir yang buruk tentang diri sendiri, tujuan hidup yang tidak jelas, dan masa depan yang lebih pesimis, semakin rendah harga diri seseorang akan lebih berisiko terkena gangguan kepribadian (Pardede, 2017)

Survei awal yang dilakukan di wilayah tembung pasar 7 maka ditemukan pasien mengalami perubahan pada perilakunya seperti menunduk, menghindari kontak mata dan memiliki kesan tertutup ketika diajak komunikasi dengan harga diri rendah situasional akibat penyakit Tb paru yang bernama Tn.Z di wilayah tembung pasar 7 .

\subsection{Rumusan Masalah}

Berdasarkan masalah yang telah di paparkan pada latar belakang maka rumusan masalah dalam askep ini yaitu Asuhan Keperawatan Pada Tn. Z Dengan Harga Diri Rendah Situasional

\subsection{Tujuan}

\subsubsection{Tujuan Umum}

Mahasiswa mampu memberikan asuhan keperawatan secara holistik dan komprehensif kepada Tn. Z Dengan Harga Diri Rendah Situasional

\subsubsection{Tujuan Khusus}

a. Mahasiswa mampu memahami pengertian, tanda dan gejala, etiologi, penatalaksanaan medis dan keperawatan Harga Diri Rendah.

b. Mahasiswa mampu melakukan pengkajian pada Tn. Z Dengan Harga Diri Rendah Situasional

c. Mahasiswa mampu melakukan menegakkan diagnosa pada Tn. Z Dengan Harga Diri Rendah Situasional 
d. Mahasiswa mampu melakukan menetapkan perencanaan pada Tn. Z Dengan Harga Diri Rendah Situasional

e. Mahasiswa mampu melakukan implementasi pada Tn. Z Dengan Harga Diri Rendah Situasional

f. Mahasiswa mampu melakukan evaluasi pada Tn. Z Dengan Harga Diri Rendah Situasional Pada Penderita Tb Paru

g. Mendokumentasikan asuhan keperawatan yang diberikan pada Tn. Z Dengan Harga Diri Rendah Situasional 


\section{BAB 2}

\section{LANDASAN TEORI}

\subsection{Konsep Tuberkulosis Paru}

\subsubsection{Definisi TB Paru}

Tuberkulosis adalah penyakit infeksi menular yang disebabkan Mycobacterium Tuberculosis yang menyerang paru-paru dan hampir seluruh organ tubuh lainya. Bakteri ini dapat masuk melalui saluran pernapasan dan saluran pencernaan dan luka terbuka pada kulit. Tetapi paling banyak melalui inhalasi droplet yang berasal dari orang yang terinfeksi bakteri tersebut Mycobacterium tuberculosis merupakan penyebab utama morbiditas dan mortalitas di seluruh dunia. Tuberkulosis (TB) sudah dikenal manusia sejak dahulu. Dinyatakan bahwa genus Mycobacterium sudah ada lebih dari 150 juta tahun yang lalu. Namun, secara spesifik M. tuberculosis mengifeksi pada manusia sekitar tiga juta tahun yang lalu dan terjadi di Afrika Timur. Secara signifikan penyakit ini dianggap sebagai phthisis pulmonalis dan wabah putih yang mengacu pada penurunan berat badan yang signifikan sehingga mengakibatkan wajah yang tampak pucat pada panderita sebagai dampak penyakit Tuberkulosis (Turgut et al., 2017).

\subsubsection{Etiologi}

Penyebab infeksi adalah kompleks Mycobacterium Tuberculosis. Kompleks ini termasuk Mycobacterium Tuberculosis dan Mycobactrium Aficanum terutama berasal dari manusia dan Mycobacterium Bovis yang berasal dari sapi. Mycobacterium lain biasanya menimbulkan gejala klinis yang sulit di bedakan dengan tuberkulosis. Etiologi penyakit dapat di identifikasi dengan kultur Ada dua macam MycobacteriumTuberculosis yaitu tipe Human dan tipe Bovin. Basil tipe Bovil berada dalam susu sapi yang menderita mastitis Tuberculosis usus. Basil tipe Human bisa berada di bercak ludah (droplet) dan diudara yang berasal dari penderita $\mathrm{TBC}$, dan orang yang terkena rentang terinfeksi bila menghirupnya 


\subsubsection{Patofisiologi}

Kuman tuberculosis masuk ke dalam tubuh melalui udara pernafasan. Bakteri yang terhirup akan dipindahkan melalui jalan nafas ke alveoli, tempat dimana mereka berkumpul dan mulai untuk memperbanyak diri. Selain itu bakteri juga dapat di pindahkan melalui sistem limfe dan cairan darah ke bagian tubuh yang lainnya. Sistem imun tubuh berespon dengan melakukan reaksi inflamasi. Fagosit menekan banyak bakteri, limfosit spesifik tuberculosis menghancurkan bakteri dan jaringan normal.

Reaksi jaringan ini mengakibatkan penumpukan eksudat dalam alveoli yang dapat menyebabkan bronchopneumonia. Infeksi awal biasanya terjadi 2 sampai 10 minggu setelah pemajaman. Massa jaringan baru yang disebut granuloma merupakan gumpalan basil yang masih hidup dan sudah mati dikelilingi oleh makrofag dan membentuk dinding protektif granuloma diubah menjadi jaringan fibrosa bagian sentral dari fibrosa ini disebut tuberkel. Bakteri dan makrofag menjadi nekrotik membentuk massa seperti keju. Setelah pemajaman dan infeksi awal, individu dapat mengalami penyakit taktif karena penyakit tidak adekuatnya sistem imun tubuh. Penyakit aktif dapat juga terjadi dengan infeksi ulang dan aktivasi bakteri. Turbekel memecah, melepaskan bahan seperti keju ke dalam bronchi. Tuberkel yang pecah menyembuh dan membentuk jaringan parut paru yang terinfeksi menjadi lebih membengkak dan mengakibatkan terjadinya bronchopneumonia

\subsubsection{Manifestasi klinis}

Tuberkulosis sering dijuluki "the great imitator" yaitu suatu penyakit yang mempunyai banyak kemiripan dengan penyakit lain yang juga memberikan gejala umum seperti lemah dan demam. Pada sejumlah penderita gejala yang timbul tidak jelas sehingga diabaikan bahkan kadang-kadang asimtomatik. Gambaran klinis TBC dapat dibagi menjadi 2 golongan, gejala respiratorik dan gejala sistemik. 
a. Gejala respiratorik meliputi:

1) Batuk: gejala batuk timbul paling dini dan merupakan gangguan yang paling sering dikeluhkan. Mual-mual bersifat non produktif kemudian berdahak bahkan bercampur darah bila sudah ada kerusakan jaringan.

2) Batuk darah: darah yang dikeluarkan dalam dahak bervariasi, mungkin tampak berupa garis atau bercak-becak darah, gumpalan darah atau darah segar dalam jumlah sangat banyak. Batuk berdahak terjadi karena pecahnya pembuluh darah.

3) Sesak nafas: gejala ini ditemukan bila kerusakan parenkim paru sudah luas atau karena ada hal-hal yang menyertai seperti efusi pleura, pneumothorax, anemia dan lain-lain.

4) Nyeri dada: nyeri dada pada TB paru termasuk nyeri pleuritik yang ringan. Gejalanya ini timbul apabila system persarafan di pleura terkena

b. Gejala sistemik meliputi

1) Demam: merupakan gejala yang sering dijumpai biasanya timbul pada sore dan malam hari mirip demam influensa, hilang timbul dan makin lama makin panjang serangannya sedang masa bebas serangan makin pendek

2) Gejala sistemik lain: gejala sistemik lain ialah keringat malam, anoreksia, penurunan berat badan serta malaise.

3) Timbulnya gejala biasanya gradual dalam beberapa minggu-bulan, akan tetapi penampilan akut dengan batu, panas, sesak nafas walaupun jarang dapat juga timbul menyerupai gejala pneumonia.Sebagian besar pasien menunjukan demam tingkat rendah, keletihan, anoreksia, penurunan berat badan, berkeringat malam, nyeri dada dan batukmenetap. Batuk pada awalnya mungkin non produktif, tetapi dapat berkembang ke arah pembentukan sputum mukopurulen dengan hemoptisis 


\subsubsection{Klasifikasi}

Berdasarkan hasil pemeriksaan dahak (BTA), TB paru dibagi atas:

1) Tuberkulosis paru BTA (+)

(1) Hasil pemeriksaan satu spesimen dahak menunjukkan BTA positif dan kelainan radiologi menunjukkan gambaran tuberculosis aktif.

(2) Hasil pemeriksaan satu spesimen dahak menunjukkan BTA positif dan biakan positif

2) Tuberkulosis paru BTA (-)

1. Hasil pemeriksaan dahak 3 kali menunjukkan BTA negatif, gambaran klinis dan kelainan radiologi menunjukkan tuberculosis aktif.

\subsubsection{Komplikasi}

1. Komplikasi dini
a. Pleuralitis
b. Efusi pleura
c. Empiema
d. Laryngitis
e. TB usus

2. Komplikasi lanjut
1) Obstruksi jalan nafas
2) Kor pulmonal
3) Amiloidosis
4) Karsinoma paru
5) Sindrom gagal nafas

\subsection{Harga Diri Rendah Situasional}

\subsubsection{Pengertian}

Harga diri rendah adalah disfungsi psikologis yang meluas dan terlepas dari spesifiknya. Masalahnya, hampir semua pasien menyatakan bahwa mereka ingin memiliki harga diri yang lebih baik. Jika kita hanya mengurangi harga 
diri rendah, banyak masalah psikologis akan berkurang atau hilang secara substansial sepenuhnya. Harga diri merupakan komponen psikologis yang penting bagi kesehatan. Banyak penelitian sebelumnya menunjukkan bahwa harga diri yang rendah sering kali menyertai gangguan kejiwaan. Harga diri yang tinggi dikaitkan dengan kecemasan yang rendah, efektif dalam kelompok dan penerimaan orang lain terhadap dirinya, sedangkan masalah kesehatan dapat menyebabkan harga diri, sehingga harga diri dikaitkan dengan hubungan interperonal yang buruk dan beresiko terjadinya depresisehingga perasaan negatif mendasari hilangnya kepercayaan diri dan harga diri individu dan menggambarkan gangguan harga diri (Wijayati et al., 2020).

Harga diri rendah berasal dari pengalaman seseorang seiring dengan pertumbuhannya, seperti : tidak ada kasi sayang, dorogan dan tantangan, tidak terdapat cinta dan penerimaan, selalu mengalami kritikan, ejekan, sarkame, dan sinisme, adanya pemukulan fisik dan pelecehan tidak adanya pengakuan dan pujian untuk prestasi, terdapat kelebihan dan keunikan yang selalu di abaikan (Pardede, Hafizudin, \& Sirait, 2021). Harga diri rendah merupakan perasaan tidak berharga, tidak berarti, dan rendah diri yang berkepanjangan akibat evaluasi negatif terhadap diri sendiri dan kemampuan diri (Keliat dkk, 2011; Pardede, 2019)

Harga diri yang tinggi dikaitkan dengan kecemasan yang rendah, efektif dalam kelompok dan penerimaan orang lain terhadap dirinya, sedangkan masalah kesehatan dapat menyebabkan harga diri, sehingga harga diri dikaitkan dengan hubungan interperonal yang buruk dan beresiko terjadinya depresisehingga perasaan negatif mendasari hilangnya kepercayaan diri dan harga diri individu dan menggambarkan gangguan harga diri. Harga diri rendah dapat digambarkan sebagai perasaan negatif terhadap diri sendiri termasuk hilangnya percaya diri dan harga diri. Harga diri rendah dapat terjadi secara situasional (trauma) atau kronis (negatif self evaluasi yang telah 
berlangsung lama). Dan dapat di ekspresikan secara langsung atau tidak langsung (nyata atau tidak nyata)(Samosir, 2020)

\subsubsection{Etiologi}

Harga diri rendah situasional disebabkan karena adanya ketidakefektifan koping individu akibat kurangnya umpan balik yang positif. Penyebab harga diri rendah juga dapat terjadi pada masa kecil sering disalahkan, jarang diberi pujian atas keberhasilannya. Saat individu mencapai masa remaja keberadaannya kurang dihargai, tidak diberi kesempatan dan tidak diterima. Menjelang dewasa awal sering gagal disekolah, pekerjaan atau pergaulan. Menurut NANDA (2017) faktor yang mempengaruhi harga diri rendah meliputi faktor Predisposisi dan faktor Presipitasi yaitu :

1. Faktor Predisposisi

a. Faktor yang mempengaruhi harga diri meliputi penolakan orang tua, harapan orang tua yang tidak realistis, kegagalan yang berulang, kurang mempunyai tanggung jawab personal, ketergantungan pada orang lain, dan ideal diri yang tidak realistis.

b. Faktor yang mempengaruhi performa peran adalah stereo type peran gender, tuntutan peran kerja, dan harapan peran budaya.

c. Faktor yang mempengaruhi identitas pribadi meliputi ketidakkepercayaan orang tua, tekanan dari kelompok sebaya, dan perubahan struktur sosial.

\section{Faktor Presipitasi}

Faktor presipitasi terjadi haga diri rendah biasanya adalah kehilangan bagian tubuh, perubahan penampilan/bentuk tubuh, kegagalan atau produktifitas yang menurun. Secara umum, ganguan konsep diri harga diri rendah ini dapat terjadi secara stuasional atau kronik. Secara situasional karena trauma yang muncul secara tiba-tiba, misalnya harus dioperasi, kecelakaan, perkosaan atau dipenjara. Termasuk dirawat dirumah sakit bisa menyebabkan harga diri rendah disebabkan karena 
penyakit fisik atau pemasangan alat bantu yang membuat klien tidak nyaman (yosep, 2016).

\section{Perilaku}

Pengumpulan data yang dilakukan oleh perawat meliputi perilaku yang objektif dan dapat diamati serta perasaan subjektif dan dunia dalam diri klien sendiri. Perilaku yang berhubungan dengan harga diri rendah salah satunya mengkritik diri sendiri, sedangkan keracuan identitasseperti sifat kepribadian yang bertentangan serta depersonalisasi (Stuart, 2018)

\subsubsection{Tanda Dan Gejala}

Menurut Saptina, (2020) tanda dan gejala pada harga diri rendah yaitu :

1. Data Subjektif
a. Mengintrospeksi diri sendiri.
b. Perasaan diri yang berlebihan.
c. Perasaan tidak mampu dalam semua hal.
d. Selalu merasa bersalah
e. Sikap selalu negatif pada diri sendiri.
f. Bersikap pesimis dalam kehidupan.
g. Mengeluh sakit fisik.
h. Pandangan hidup yang terpolarisasi.
i. Menentang kemampuan diri sendiri.
j. Menjelek-jelekkan diri sendiri.
k. Merasakan takut dan cemas dalam suatu keadaan.
1. Menolak atau menjauh dari umpan balik positif.
m. Tidak mampu menentukan tujuan.

2. Data Obyektif

1. Produktivitas menjadi menurun.

2. Perilaku distruktif yang terjadi pada diri sendiri.

3. Perilaku distruktif yang terjadi pada orang lain. 
4. Penyalahgunaan suatu zat.

5. Tindakan menarik diri dari hubungan sosial.

6. Mengungkapkan perasaan bersalah dan malu.

7. Muncul tanda depresi seperti sukar tidur dan makan.

8. Gampang tersinggung dan mudah marah.

\subsubsection{Rentang Respon}

Konsep diri merupakan aspek kritikal dan dasar dari perilaku individu. Individu dengan konsep diri yang positif dapat berfungsi lebih efektif yang terlihat dari kemampuan interpersonal, kemampuan intelektual dan penguasaan lingkungan. Konsep diri yang negatif dapat dilihat dari hubungan individu an sosial yang maladaptif.

Gambar Rentang respon konsep - diri ( Stuart G.W, 2018)

Respon Adaptif Respon Maladaptif

Aktualisasi diri Konsep diri Harga diri kerancuan identitas Depersonalisasi Positif Rendah

Aktualisasi diri adalah pernyataan diri tentang konsep diri yang positif dengan latar belakang pengalaman nyata yang sukses dan dapat diterima. Konsep diri positif merupakan bagaimana seseorang memandang apa yang ada pada dirinya meliputi citra dirinya. Ideal dirinya harga dirinya, penampilan peran serta identitas dirinya secara positif. Hal ini akan menunjukan bahwa individu itu akan menjadi individu yang sukses.

Harga diri rendah Situasional merupakan perasaan negatif terhadap dirinya sendiri, termasuk kehilangan percaya diri, tidak berharga, tidak, berguna, pesimis tidak ada harapan dan putus asa. Adapun perilaku yang berhubungan dengan harga diri yang rendah yaitu mengkritik diri sendiri atau orang lain, penurunan produktivitas, destruktif yang diarahkan kepada orang lain, 
ganguan dalam berhubungan, perasaan tidak mampu, rasa bersalah, perasaan negatif mengenai tubuhnya sendiri, keluhan fisik, menarik diri secara sosial, khawatir, serta menarik diri dari realitas.

Keracuan identitas merupakan suatu kegagalan individu untuk mengintegrasikan berbagai identifikasi masa kanak-kanak kedalam kepribadian psikososial dewasa yang harmonis. Adapun perilaku yang berhubungan dengan keracuan identitas yaitu tidak ada kode moral, sifat kepribadian yang bertentangan, hubungan interpersonal eksploitatif, perasaan hampa. Perasaan mengambang tentang diri sendiri, tingkat ansietas yang tinggi, ketidak mampuan untuk empati terhadaapa orang lain.

Despersonalisasi merupakan suatu perasaan yang tidak realistis dimana klien tidak dapat membedakan stimulus dari dalam atau luar dirinya. Individu mengalami kesulitan untuk membedakan dirinya sendiri dari orang lain, dan tubuhnya sendiri merasa tidak nyata dan asing baginya.

\subsubsection{Proses Terjadinya HDR Stresor}

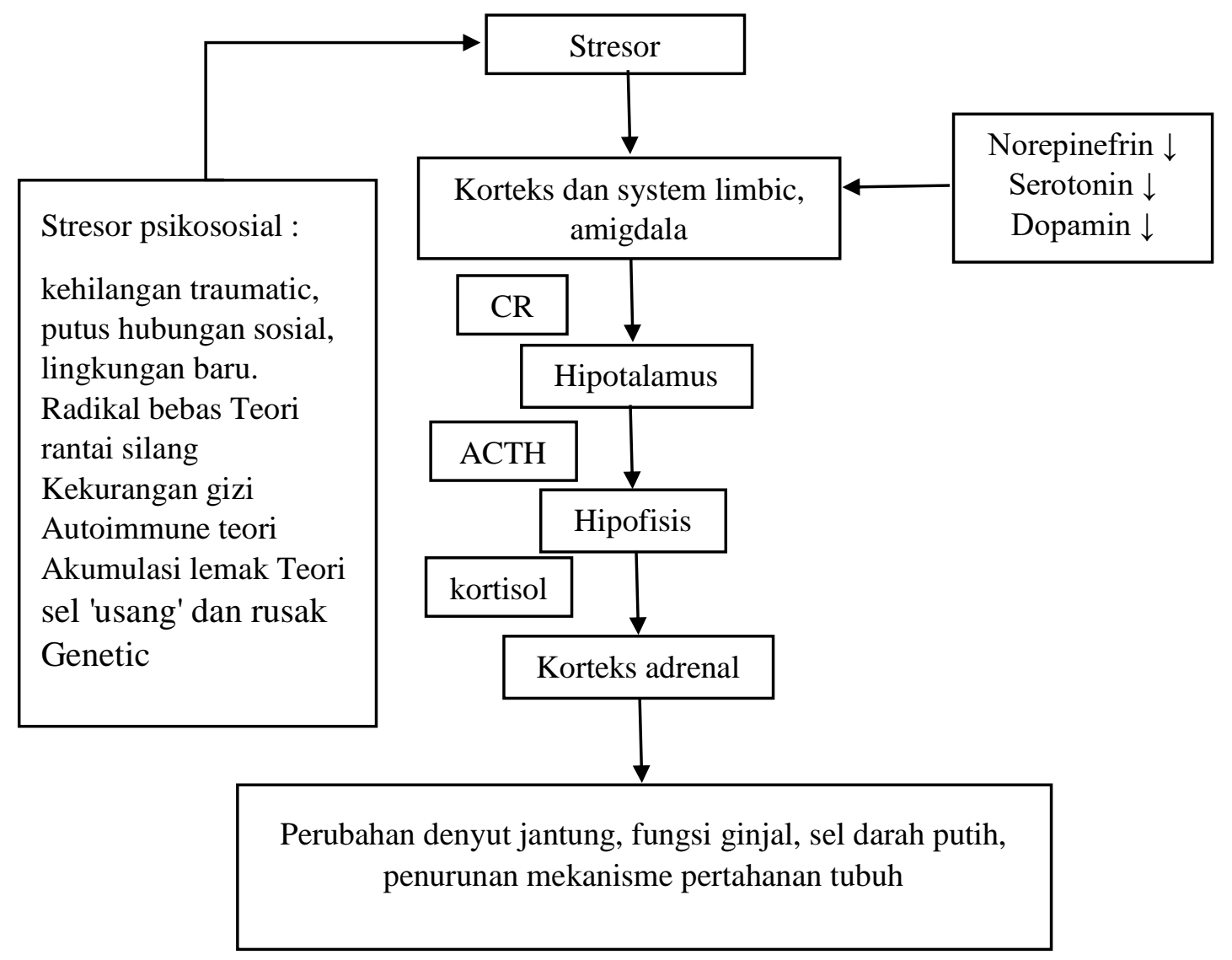




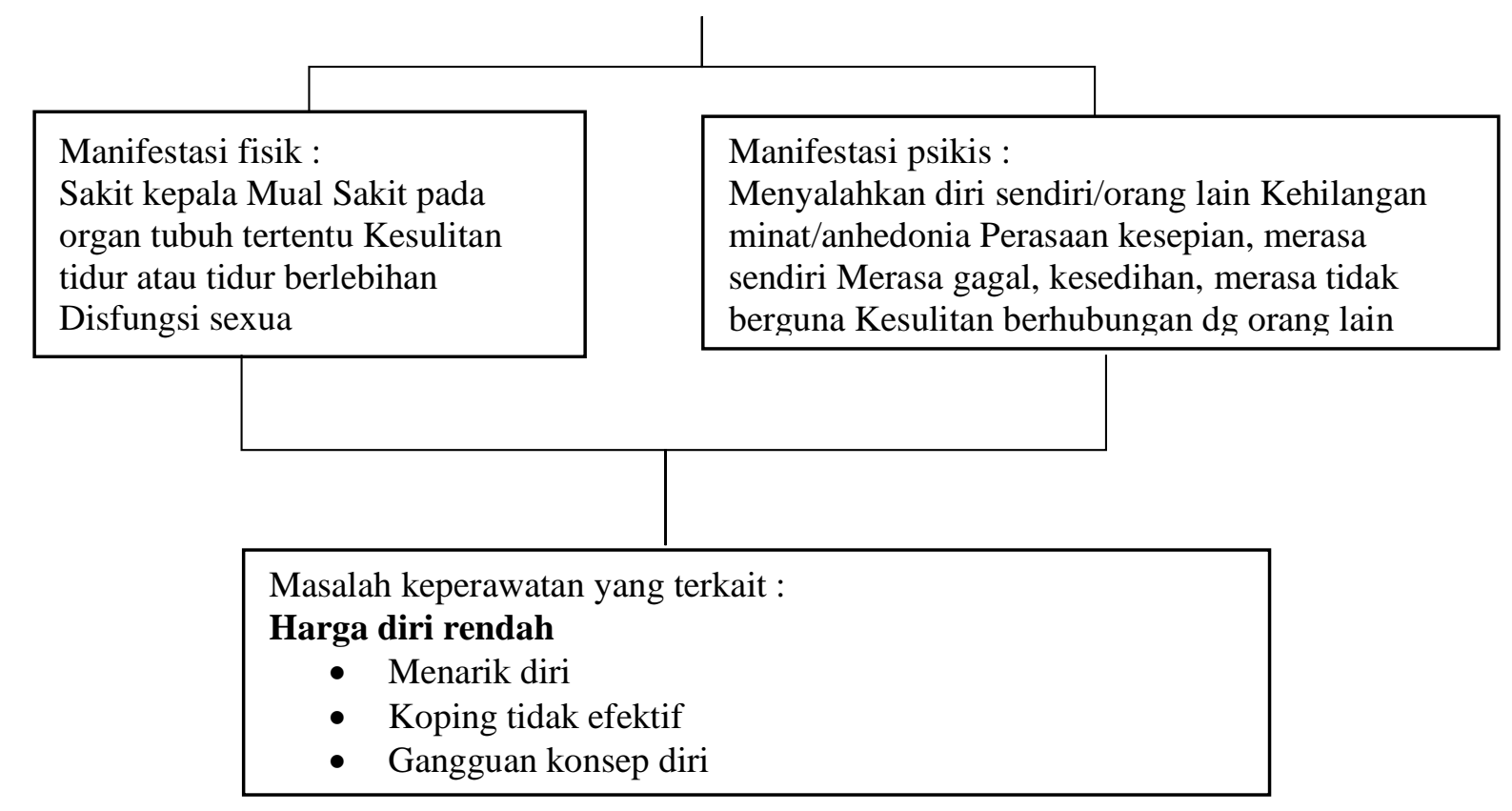

\subsubsection{Karakteristik}

a. Mengatakan hal yang negatif tentang diri sendiri dalam waktu lama dan terus menerus

b. Mengekspresikan sikap malu/ minder/ rasa bersalah

c. Kontak mata kurang/ tidak ada

d. Selalu mengatakan ketidak mampuan/kesulitan untuk mencoba sesuatu

e. Bergantung pada orang lain

f. Tidak asertif

g. Pasif dan hipoaktif

h. Bimbang dan ragu-ragu

i. Menolak umpan balik positif dan membesarkan umpan balik negatif mengenai dirinya

Faktor yang berhubungan

a. Sikap keluarga yang tidak mendukung

b. Penolakan 
c. Kegagalan

Untuk menegakkan diagnosa ini perlu didapatkan data utama

a. Kontak mata kurang/tidak ada

b. Mengungkapkan secara verbal rasa minder/malu/bersalah

c. Mengatakan hal yang negatif tentang diri sendiri

d. Sering mengatakan ketidakmampuan melakukan sesuatu

\subsubsection{Pohon Masalah}

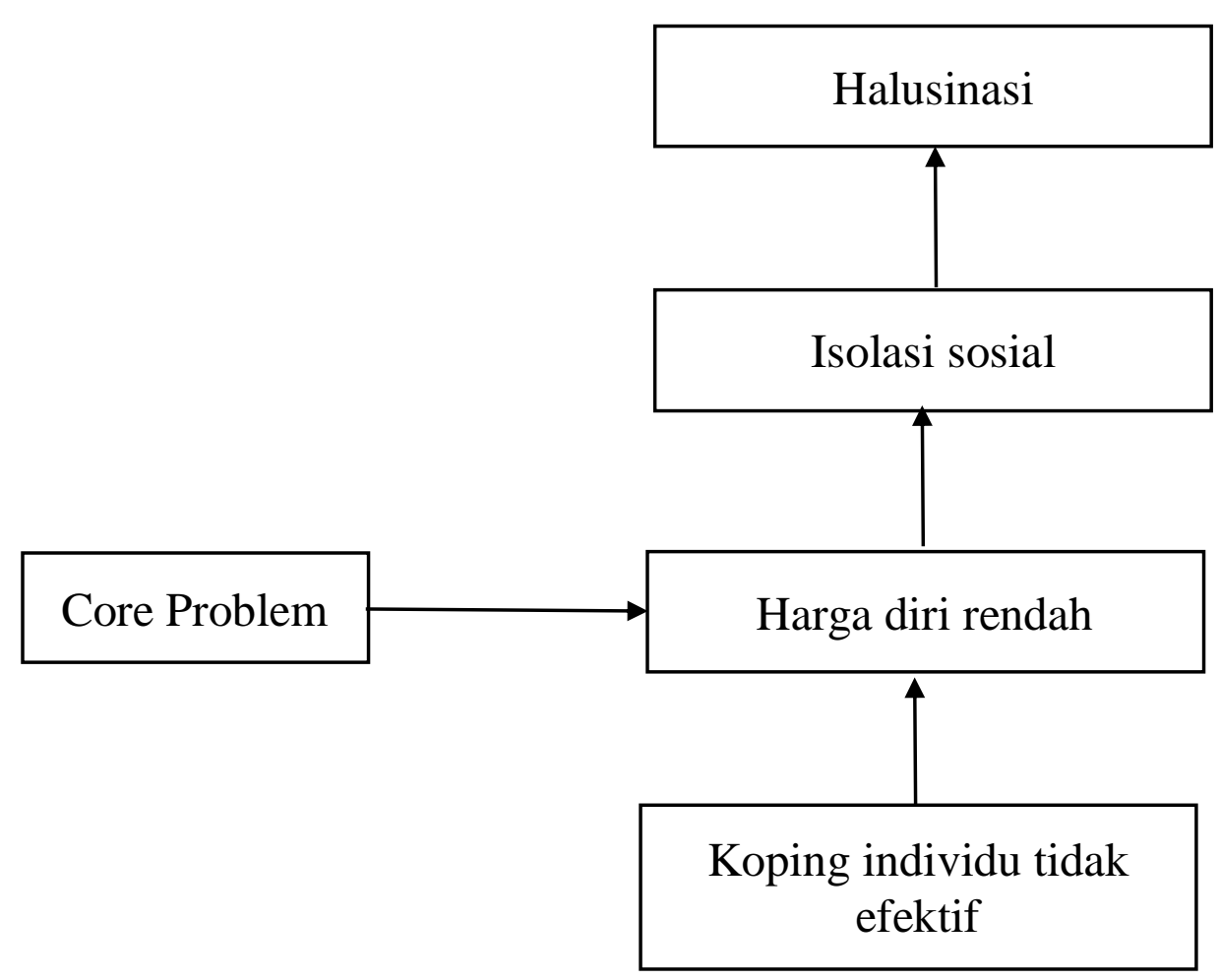

\subsubsection{Faktor Predisposisi dan Faktor Presipitasi Harga Diri Rendah}

Menurut (Suryani \& Efendi, 2020)fakor predisposisi dan faktor presipitasi harga diri rendah ialah :

1. Aspek Biologis Sebagian besar pasien memiliki riwayat gangguan jiwa sebelumnya (75\%), Sebagian kecil memiliki riwayat genetik (25\%). Faktor genetik berperan dalam mencetuskan terjadinya gangguan jiwa pada diri seseorang. Sadock dan Sadock (2007) menyampaikan bahwa genetik memiliki peran pada pasien skizofrenia. Seseorang beresiko $10 \%$ 
jika salah satu orang tua menderita gangguan dan jika kedua orang tua memiliki riwayat gangguan maka resiko akan lebih besar, yaitu menjadi $40 \%$.

2. Aspek Psikologis Pasien HDR kronis yang diberikan terapi kognitif memiliki riwayat psikologis kurang percaya diri (90\%). Menurut Stuart (2016) bahwa faktor psikologis meliputi konsep diri, intelektualitas, kepribadian, moralitas, pengalaman masa lalu, koping dan keterampilan komunikasi secara verbal mempengaruhi perilaku seseorang dalam hubungannya dengan orang lain.

3. Aspek Sosial Budaya Pasien yang diberikan terapi kognitif dan psikoedukasi keluarga memiliki masalah sosial budaya yang sangat berpengaruh yaitu tidak memiliki teman (85\%), konflik keluarga (80\%) dan status ekonomi rendah (70\%). Townsend (2009) menyatakan bahwa status sosioekonomi yang rendah lebih banyak mengalami gangguan jiwa dibandingkan tingkat sosio ekonomi tinggi.

\subsubsection{Manifestasi Klinis Harga Diri Rendah}

Tanda dan gejala harga diri rendah

1. Perasaan malu terhadap diri sendiri akibat adanya penyakit atau akibat tindakan terhadap penyakit.

2. Rasa bersalah terhadap diri sendiri. Individu merasa tidak mampu dan tidak berguna dan memandang dirinya lemah.

3. Gangguan hubungan sosial, seperti menarik diri dari masyarakat. Individu merasa tidak berguna sehingga klien merasa lebih suka meyendiri dan enggan untuk berinteraksi dengan lingkungan masyarakat.

4. Merendahkan martabat. Individu merasa dirinya lemah merasa bodoh, merasa tidak mampu dalam melakukan segala hal, dan individu merasa tidak tahu apa-apa, mengabaikan bahkan menolak kemampuan yang dimiliki sehingga produktivitas individu menurun. 
5. Percaya diri kurang. Individu merasa ragu-ragu dalam mengambil keputusan, individu tidak memiliki rasa percaya pada dirinya dan individu selalu memandnag dirinya negatif.

6. Mencederai diri sendiri dan orang lain. Akibat harga diri rendah individu memandang hidupnya pesimis, tidak berguna sehingga terdorong untuk merusak atau mengakhiri hidupnya. Bahkan klien dengan harga diri rendah timbul perasaan benci dan dapat menimbulkan perilaku kekerasan terhadap lingkungan sekitar

\subsubsection{Proses Terjadinya Harga Diri Rendah}

Harga diri rendah kronis terjadi merupakan proses kelanjutan dari harga diri rendah situasional yang tidak terselesaikan. Atau dapat juga terjadi karena individu tidak pernah mendapat feed back dari lingkungan tentang prilaku klien sebelumnya bahkan kecendrungan lingkungan yang selalu memberi respon negatif mendorong individu menjadi harga diri rendah. Harga diri rendah kronis terjadi disebabkan banyak faktor. Awalnya individu berada pada suatu situasi yang penuh dengan stressor (krisis), individu berusaha menyelesaikan krisis tetapi tidak mampu atau merasa gagal menjalankan fungsi dan peran. Penilaian individu terhadap diri sendiri karena kegagalan menjalankan fungsi dan peran adalah kondisi harga diri rendah situasional, jika lingkungan tidak memberi dukungan positif atau justru menyalahkan individu dan terjadi secara terus menerus akan mengakibatkan individu mengalami harga diri rendah kronis(Samosir, 2020)

\subsection{Asuhan Keparawatan}

1. Data Pengkajian

\section{a. Faktor Predisposisi}

1. Biologi

a. Genetik : riwayat adanya trauma yang menyebabkan lesi pada daerah frontal, temporal dan limbic, pada anak yang kedua orangtuanya tidak menderita, kemungkinan terkena penyakit adalah $1 \%$. Sementara pada 
anak yang salah satu orangtuanya menderita kemungkinan terkena adalah 13\%. Dan jika kedua orangtuanya penderita maka resiko terkena adalah $35 \%$, riwayat janin pada saat prenatal dan perinatal meliputi trauma, penurunan oksigen pada saat melahirkan, prematur, preeklamsi, malnutrisi, stres, ibu perokok, alkohol, pemakaian obat-obatan, infeksi, hipertensi dan agen teratogenik

b. Nutrisi : adanya riwayat gangguan nutrisi ditandai dengan penurunan BB, rambut rontok, anoreksia, bulimia nervosa,

c. Keadaan kesehatan secara umum : riwayat kesehatan umum, misalnya kurang gizi, kurang tidur, gangguan irama sirkadian, kelemahan, infeksi

d. Sensitivitas biologi : riwayat penggunaan obat, riwayat terkena infeksi dan trauma, radiasi dan riwayat pengobatannya

e. Paparan terhadap racun : paparan virus influenza pada trimester 3 kehamilan, riwayat keracunan $\mathrm{CO}$, asbestos

2. Psikologis

a. Intelegensi : riwayat kerusakan struktur di lobus frontal dimana lobus tersebut berpengaruh kepada proses kognitif, suplay oksigen terganggu dan glukosa

b. Ketrampilan verbal :gangguan keterampilan verbal akibat faktor komunikasi dalam keluarga, seperti : komunikasi peran ganda, tidak ada komunikasi, komunikasi dengan emosi berlebihan, komunikasi tertutup, riwayat kerusakan yang mempengaruhi fungsi bicara, misalnya Stroke, trauma kepala

c. Moral : riwayat tinggal di lingkungan yang dapat mempengaruhi moral individu, misalnya lingkungan keluarga yang broken home, konflik, Lapas.

d. Kepribadian : mudah kecewa, kecemasan tinggi, mudah putus asa, menutup diri

e. Pengalaman masa lalu : orangtua yang otoriter, orangtua yang selalu membandingkan, konflik orangtua, anak yang dipelihara oleh ibu yang 
suka cemas, terlalu melindungi, dingin dan tak berperasaan, ayah yang mengambil jarak dengan anaknya, penolakan atau tindakan kekerasan dalam rentang hidup klien, penilaian negatif yang terus menerus dari orang tua

f. Konsep diri : ideal diri yang tidak realistis, identitas diri tak jelas, harga diri rendah, krisis peran, gambaran diri negatif

g. Motivasi :riwayat kurangnya penghargaan, riwayat kegagalan

h. Pertahanan psikologi : ambang toleransi terhadap stress rendah, riwayat gangguan perkembangan

i. Self control : riwayat tidak bisa mengontrol stimulus yang datang, misalnya suara, rabaan, penglihatan, penciuman, pengecapan, gerakan.

\section{Sosiokultural}

a. Usia : riwayat tugas perkembangan yang tidak selesai

b. Gender : riwayat ketidakjelasan identitas, riwayat kegagalan peran gender,

c. Pendidikan : pendidikan yang rendah, riwayat putus dan gagal sekolah,

d. Pendapatan : penghasilan rendah

e. Pekerjaan : pekerjaan stresful, Pekerjaan beresiko tinggi

f. Status sosial : tuna wisma, Kehidupan terisolasi

g. Latar belakang Budaya : tuntutan sosial budaya seperti paternalistik, stigma masyarakat

h. Agama dan keyakinan : riwayat tidak bisa menjalankan aktivitas keagamaan secara rutin, rutin, kesalahan persepsi terhadap ajaran agama tertentu

i. Keikutsertaan dalam politik : riwayat kegagalan dalam politik

j. Pengalaman sosial : perubahan dalam kehidupan, mis bencana, perang, kerusuhan, dll, tekanan dalam pekerjaan, kesulitan mendapatkan pekerjaan,

k. Peran social : isolasi sosial khususnya untuk usia lanjut, stigma yang negatif dari masyarakat, diskriminasi, stereotype, praduga negatif 
b. Faktor Presipitasi

1. Biologi : genetic, nutrisi, keadaan kesehatan secara umum, sensitivitas biologi, paparan terhadap racun.

2. Psikologis : intelegensi, ketrampilan verbal, moral, kepribadian, pengalaman masa lalu, konsep diri, motivasi, pertahanan psikologi, self control.

3. Sosiokultural : usia, gender, pendidikan, pendapatan, pekerjaan, status social, latar belakang Budaya, agama dan keyakinan, keikutsertaan dalam politik, pengalaman sosial, peran sosial

c. Penilaian terhadap stresor Penilaian terhadap stresor dapat dikaji dari berbagai sisi, dimulai dari segi kognitif yaitu apa yang dipikirkan klien tentang stresor yang dialaminya, dari segi afekti yaitu bagaimana perasaannya, dari segi fisiologis yaitu bagaimana perubahan fisik yang terjadi akibat stresor, dari segi perilaku yaitu bagaimana perilaku yang ditampilkan terkait stresor dan dari sesi sosial yaitu bagaimana hubungan klien dengan orang lain terkait stresor yang dialaminya.

d. Sumber Koping

Kondisi status ekonomi, kemampuan menyelesaikan masalah, dukungan sosial, dan keyakinan budaya.

e. Mekanisme Koping

Menurut Stuart (2018) mekanisme kopng termasuk pertahanan koping jangka pendek atau jangka panjang serta penggunaan mekanisme pertahanan ego untuk melindungi diri sendiri dalam menghadapi persepsi diri yang menyakitkan. Pertahanan tersebut mencakup berikut ini:

1) Aktivitas yang memberikan pelarian sementara dari krisis identitas diri (misalnya, konser musik, bekerja keras, menonton televise secara obsesif)

2) Aktivitas yang memberikan identitas pengganti sementara (misalnya 
dalam club sosial, agama, politik, kelompok, gerakan atau geng).

3) Aktivitas yang sementara menguatkan atau meningkatkan perasaan diri yang tidak menentu (misalnya, olahraga yang kompetitif, prestasi akademik, kontes untuk mendapatakan popularitas).

Pertahanan jangka panjang mencakup berikut ini:

1) Penutupan identitas: adopsi identitas premature yang diinginkan oleh orang terdekat tanpa memerhatikan keinginan, aspirasi, atau potensi diri individu.

2) Identitas negatif: asumsi identitas yang tidak sesuai dengan nilai dan harapan yang diterima masyarkat.

\section{Diagnosis Keperawatan Jiwa}

Perawat kesehatan jiwa menganalisis data pengkajian dalam menentukan diagnosis. Landasan untuk memberikan asuhan keperawatan kesehatan jiwa adalah pengenalan dan mengidentifikasi pola respons terhadap masalah kesehatan jiwa atau penyakit psikiatri yang actual dan pontensial (Yusuf et. al, 2015).

\section{Perencanaan}

Perawat kesehatan jiwa mengembangkan rencana asuhan yang menggambarkan intervensi untuk mencapai hasil yang diharapkan. Rencana asuhan digunakan untuk memandu intervensi terapeutik secara sistematis dan mencapai hasil pasien yang diharapkan (Yusuf et. al, 2015).

a. Tindakan Keperawatan

1. Tindakan keperawatan pada pasien:

1) Tujuan:

a) Pasien dapat mengindentifikasi kemampuan dan aspek positif yang di miliki.

b) Pasien dapat menilai kemampuan yang dapat di gunakan.

c) Pasien dapat menetaptan/memilih kegiatan yang sesuai kemampuan.

d) Pasien dapat melatih kegiatan yang sudah dipilih, sesuai 
kemampuan.

e) Pasien dapat menyusun jadwal untuk melakukan kegiatan yang sudah dilatih.

\section{Tindakan Keperawatan}

1) Mengindentifikasi kemampuan dan aspek positif yang yang masih di miliki pasien. Untuk membantu pasien dapat mengungkapkan kemempiuan dan aspek positif yang masih dimilikinya, perawat dapat:

a. Mendiskusikan bahwa sejumlah kemampuan dan aspek positif yang dimiliki pasien seperti kegiatan pasien di rumah sakit, dalam keluarga dan lingkungan adanuya keluarga dan lingkungan terdekat pasien

b. Beri pujian yang realistik/nyata dan hindarkan setiap kali bertemu dengan pasien penilaian yang negative

2) Membantu pasien menilain kemampuan yang dapat digunakan. Untuk tindakan tersebut saudara dapat :

a. Mendiskusikan dengan pasien kemempuan yang masih dapatb digunakan saat ini.

b. Bantu pasien menyebutkanya dan memberi penguatan terhadap kemampuan diri yang diungkapkan pasien.

c. Perlihatkan respon yang kondusif dan menjadi pendengar yang aktif.

3) Membantu pasien memilih atau menetapkan kemampuan yang akan dilatih Tindakan keperawatan yang dapat dilakukan adalah:

a. Mendiskusikan dengan pasien beberapa kegiatan yang dapat dilakukan dan dipilih sebagai kegiatan yang akan pasien lakukan sehari-hari

b. Bantu pasien menentukan kegiatan mana yang dapat pasien lakukan secara mandiri, mana kegiatan yang memerlukan bantuan minimal dari keluraga atau lingkungan terdekat pasien 
berikan contoh pelaksanakan kegiatan yang dilakukan pasien. Susun bersama pasien dan buat daftar kegitan sehari-hari pasien.

4) Melatih kemampuan yang dimiliki pasien.

Tindakan keperawatan tersebut saudara dapat melakukan:

a. Mendiskusikan dengan pasien untuk melatih kemampuan yang dipilih

b. Bersama pasien memperagakan kegiatan yang ditetapkan

c. Berika dukungan dan pujian pada setiap kegiatan yang dapat dilakukan pasien.

5) Membantu menyusun jadwal pelaksanaan kemampuan yang dilatih Untuk mencapai tujuan tindakan keperawatan tersebut saudara dapat melakukan hal-hal berikut:

a. Memberi kesempatan pada pasien untuk mencoba kegiatan yang telah dilatihkan.

b. Beri pujian atas kegiatan - kegiatan yang dapat dilakukan pasien setiap hari

c. Susun jadwal untuk melaksanakan kegiatan yang telah dilatih.

d. Berikan kesempatan mengungkapkan perasaanya setelah pelaksanaanya kegiatan.

\section{Konseling}

Perawat kesehatan jiwa menggunakan intervensi konseling untuk membantu pasien meningkatkan atau memperoleh kembali kemampuan koping, memelihara kesehatan mental, dan mencegah penyakit atau ketidak mampuan menta (Yusuf et. al, 2015).

\section{Terapi Lingkungan}

Perawat kesehatan jiwa memberikan, membentuk, serta mempertahankan suatu lingkungan yang terapeutik dalam kolaborasinya dengan pasiendan pemberian pelayanan kesehatan lain (Yusuf et. al, 2015). 


\section{Aktivitas Asuhan Mandiri}

Perawat kesehatan jiwa membentuk intervensi sekitar aktivitas kehidupan sehari-hari pasien untuk memelihara asuhan mandiri dan kesejhteraan jiwa dan fisik (Yusuf et. al, 2015).

\section{Intervensi psikobiologis}

Perawat kesehatan jiwa menggunakan pengetahuan intervensi psikobiologis dan menerapkan keterampilan klinis untuk memulihkan kesehatan pasien dan mencegah ketidakmapuan lebih lanjut (Yusuf et. al, 2015).

7. Penyuluhan kesehatan

Perawat kesehatan jiwa, melalui penyuluhan kesehatan, serta membantu pasien dalam mencapai pola kehidupanyang memuaskan produktif dan sehat (Yusuf et. al, 2015).

8. Manajemen kasus

Perawat kesehatan jiwa menyajikan manejemen kasus untuk mengkordinasi kesehatan yang komprehensif serta memastikan kesenambungan asuhan (Yusuf et. al, 2015).

9. Pemeliharaan dan peningkatan kesehatan

Perawat kesehatan jiwa menerapkan strategi dan intervensi untuk meningkatkan, memelihara kesehatan jiwa, serta mencegah penyakit jiwa (Yusuf et. al, 2015).

\section{Psikoterapi}

Spesialis yang bersetifikasi dalam keperawatan kesehatan jiwa menggunakan psikoterapi individu, psikoterapi kelompok, psikoterapi keluarga, psikoterapi anak, serta pengobatan terapeutik lain untuk membantu pasien untuk memelihara kesehatan jiwa, mencegah penyakit jiwa dan ketidakmampuan, serta memperbaiki atau mencapai kembali status kesehatan dan kemampuan fungsional pasien (Yusuf et. al, 2015). 


\section{Preskripsi Agen Farmakologis}

Spesialis yang bersertifikasi memberikan konsultasi kepada pemberi pelayanan kesehatan dan lainnya untuk memengaruhi rencana asuhan kepada pasien, dan memperkuat kemampuan yang lain untuk memberikan pelayanan kesehatan jiwa dan psikiatri serta membawa perubahan dalam setiap pelayanan kesehatan jiwa dan psikiatri (Yusuf et. al, 2015).

\section{Evaluasi}

Perawat kesehatan jiwa mengevaluasi perkembangan pasien dalam mencapai hasil yang diharapkan. Asuhan keperawatan adalah proses dinamik yang melibatkan perusahaan dalam status kesehatan pasien sepanjang waktu, pemicu kebutuhan terhadap data baru, berbagai diagnosis, dan modifikisi rencana asuhan. Oleh karena itu, evaluasi merupakan suatu proses penilaian berkesinambungan tentang pengaruh intervensi keperawatan dan regimen pengobatan terhadap status kesehatan pasien dan hasil kesehatan yang diharapkan (Yusuf et. al, 2015). 


\section{BAB 3}

\section{ASUHAN KEPERAWATAN}

\subsection{Pengkajian Keperawatan}

\begin{tabular}{|l|l|}
\hline Nama : Tn. Z & Kondisi saat MRS : \\
Usia : 19 tahun & mual, kadang-kadang muntah, lemas dan tidak nafsu makan \\
Tahun no reg : - & yang telah berlangsung selama 1 bulan yang lalu \\
Rungan : - & kondisi saat ini : \\
Tgl masuk rs : - & Tn. Z mengeluh sesak napas dan nyeri dada saat batuk. \\
Tgl pengkajian : 09 oktober 2021 & Klien mengatakan batuk-batuk dan jika batuk klien \\
Alamat : & kesulitan untuk bernapas dan aktivitasnya terganggu, dan \\
& tidak bisa tidur dari kemarin karena sesak napas \\
\hline
\end{tabular}

3.1.1 Faktor Predisposisi Dan Faktor Presipitasi

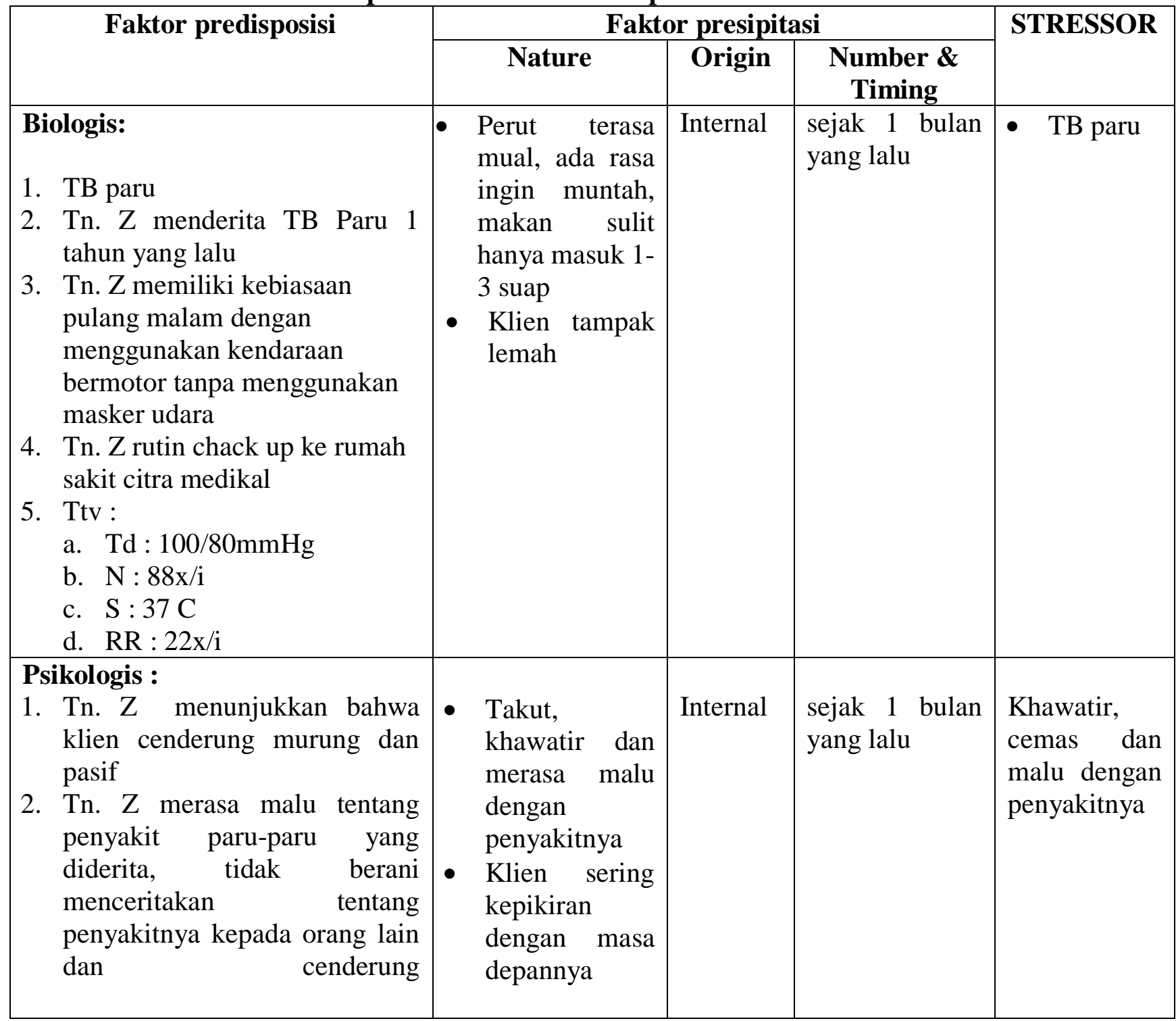




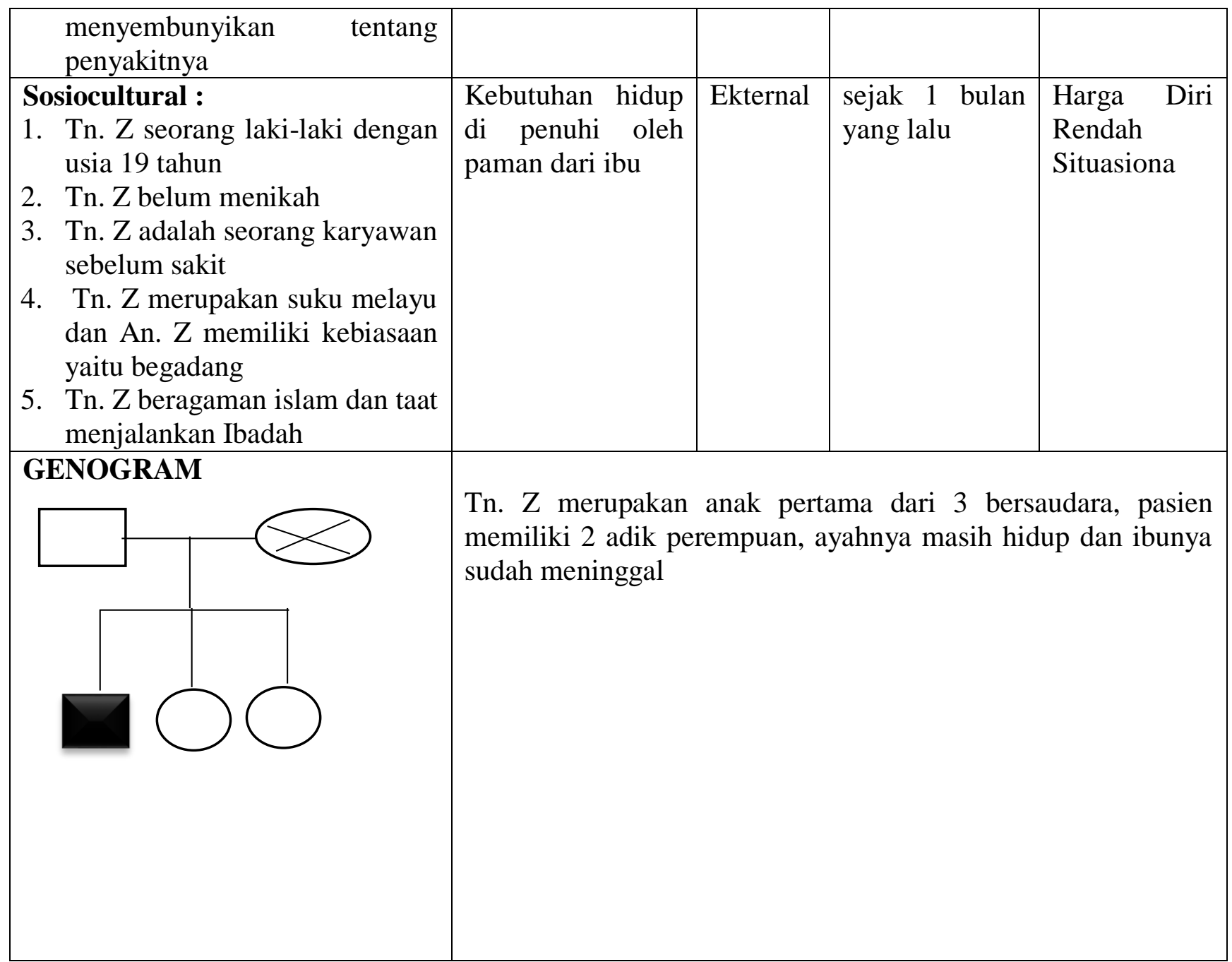

Ket<smiles>C1CCC1</smiles>

Laki-Laki Pasien

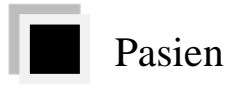

$\bigcirc$ Perempuan

$\bigotimes$ Meninggal Dunia

$\bigotimes$ Meninggal Dunia

- - . Tinggal Bersama Keluarga 
3.1.2 Penilaian (Respon)Terhadap Stressor

\begin{tabular}{|c|c|c|c|c|c|c|}
\hline STRESSOR & KOGNITIF & AFEKTIF & FISIOLOGIS & PERILAKU & SOSIAL & $\begin{array}{c}\text { DIAGNOSA } \\
\text { KEPERAWATAN }\end{array}$ \\
\hline $\begin{array}{l}\text { BIOLOGIS } \\
\text { - } \quad \text { Tb Paru }\end{array}$ & 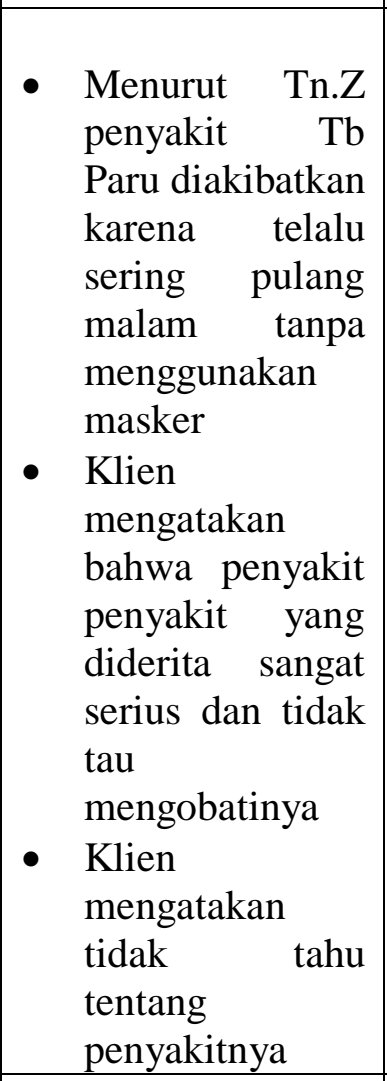 & 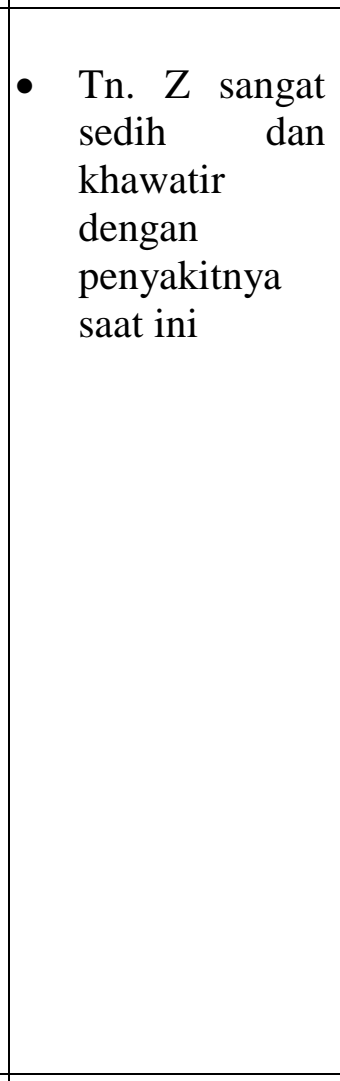 & 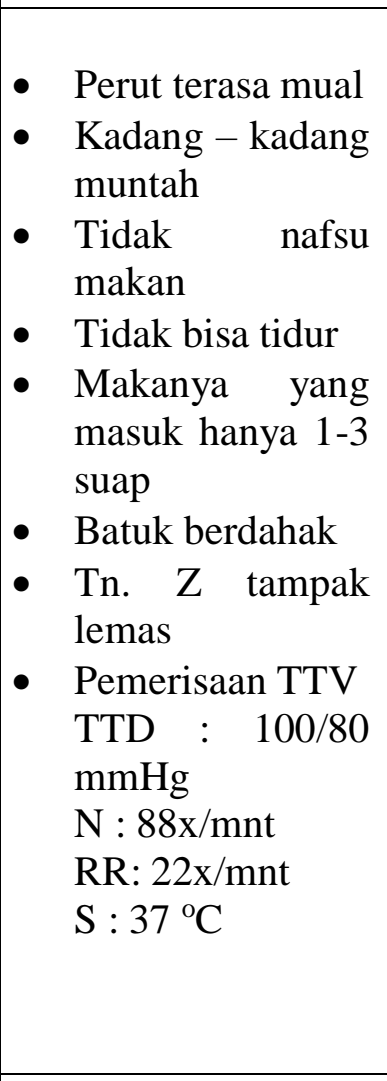 & $\begin{array}{l}\text { - } \text { Tn. Z cenderung } \\
\text { murung dan pasif } \\
\text { - } \\
\text { Ekspresi tampak } \\
\text { lesu } \\
\text { - } \text { Tn. Z tampak } \\
\text { lemah, sedih dan } \\
\text { khawatir }\end{array}$ & $\begin{array}{l}\text { - Pasien } \\
\text { mengunjungi } \\
\text { rumah sakit } \\
\text { untuk } \\
\text { mendapatkan } \\
\text { kesembuhan } \\
\text { terhadap } \\
\text { penyakit yang } \\
\text { dihadapinya } \\
\text { saat ini }\end{array}$ & $\begin{array}{ll}\text { - } & \text { Kurang } \\
& \text { pengetahuan }\end{array}$ \\
\hline \begin{tabular}{|l} 
PSIKOLOGIS \\
- $\quad$ Merasa \\
$\quad$ Malu tentang \\
\end{tabular} & $\begin{array}{ll}\text { - Tn. } & \mathrm{Z} \\
\text { mengatakan } & \end{array}$ & $\begin{array}{l}\text { - Merasa marah } \\
\text { terhadapa }\end{array}$ & $\begin{array}{ll}\text { - } & \text { Sedih } \\
\text { - } & \text { Malu }\end{array}$ & $\begin{array}{lll}\text { - } & \text { Tn.Z } & \text { merasa } \\
\text { malu } & \text { dengan }\end{array}$ & - $\begin{array}{l}\text { Tn. } \mathrm{Z} \\
\text { mengikuti }\end{array}$ & - Ansietas \\
\hline
\end{tabular}




\begin{tabular}{|c|c|c|c|c|c|c|}
\hline $\begin{array}{l}\text { penyakit } \\
\text { paru-paru } \\
\text { yang } \\
\text { diderita, } \\
\text { cemas dan } \\
\text { khawatir } \\
\text { dengan } \\
\text { kondisi saat } \\
\text { ini }\end{array}$ & $\begin{array}{ll} & \text { sangat sedih } \\
\text { - } & \text { Sedih dengan } \\
\text { penyakiynya } \\
\text { - } \\
\text { Mengaku } \\
\text { bingung } \\
\text { mengenai } \\
\text { penyakitnya } \\
\text { - Tn.Z tidak tahu } \\
\text { pengobatan } \\
\text { seperti apa yang } \\
\text { dapat di } \\
\text { lakukannya }\end{array}$ & $\begin{array}{l}\text { penyakitnya } \\
\text { yang tidak } \\
\text { bsembuh- } \\
\text { sembuh } \\
\text { Merasa malu } \\
\text { dan cemas } \\
\text { dengan } \\
\text { kondisi } \\
\text { penyakitnya }\end{array}$ & $\begin{array}{l}\text { penyakitnya } \\
\text { - Takut orang lain } \\
\text { mengetahui } \\
\text { penyakitnya saat } \\
\text { ini } \\
\text { - } \begin{array}{l}\text { Merasa tidak } \\
\text { berguna }\end{array}\end{array}$ & $\begin{array}{l}\text { penyakitnya } \\
\text { - Tampak cemas } \\
\text { dan khawatir } \\
\text { - Tn.Z tampak } \\
\text { murung dan pasif }\end{array}$ & $\begin{array}{l}\text { program } \\
\text { pengobatan } \\
\text { yang diberikan } \\
\text { kepadanya } \\
\text { - Tn.Z kurang } \\
\text { dalam } \\
\text { bersosialisasi } \\
\text { dengan tetangga } \\
\text { - Hubungan Tn.Z } \\
\text { dengan keluarga } \\
\text { tampak baik }\end{array}$ & \\
\hline \begin{tabular}{l}
\multicolumn{1}{c}{ SOSIAL } \\
BUDAYA \\
- Tn.Z sering \\
memikirkan \\
kelurganya \\
dan merasa \\
kasihan \\
terhadap \\
keluarganya
\end{tabular} & $\begin{array}{l}\text { - Tn. Z merasa } \\
\text { tidak berdaya } \\
\text { dengan } \\
\text { keadaanya saat } \\
\text { ini yang tidak } \\
\text { bisa membantu } \\
\text { keluarga nya } \\
\text { - Tn.Z merasa } \\
\text { bahwa diri nya } \\
\text { tidak berguna } \\
\text { - Tn.Z merasa } \\
\text { kasihan dan } \\
\text { sedih terhadap } \\
\text { keluarganya }\end{array}$ & $\begin{array}{l}\text { Merasa } \\
\text { khawatir dan } \\
\text { sedih kepada } \\
\text { keluarga nya } \\
\text { terkhususnya } \\
\text { kepada } \\
\text { ayahnya yang } \\
\text { mencari } \\
\text { nafkah } \\
\text { Merasa } \\
\text { bersalah } \\
\text { karena tidak } \\
\text { bisa berbuat } \\
\text { apa- apa } \\
\text { Tn.Z merasa } \\
\text { dirinya sangat } \\
\text { menyedihkan }\end{array}$ & \begin{tabular}{lll} 
- & \multicolumn{2}{l}{ Mual } \\
- & Kadang - kadang \\
& muntah & \\
- & Tidak nafsu \\
& makan & \\
- & Dada terasa sesak \\
- & Sulit tidur & \\
- & Badan & tersa \\
& lemas & \\
- & Wajah tampak \\
& pucat
\end{tabular} & \begin{tabular}{|llr} 
- & Tn.Z & sering \\
& melamun & \\
- & Kontak mata \\
& kurang fokus \\
- & Volume r suara \\
& mengecil & \\
- & Tn.Z tampak \\
& gelisah r dan \\
& khawatir r
\end{tabular} & $\begin{array}{l}\text { - Hubungan Tn. } \\
\mathrm{Z} \text { dengan } \\
\text { anggota } \\
\text { keluarga sangat } \\
\text { baik } \\
\text { - Hubungan Tn. } \\
\mathrm{Z} \text { dengan } \\
\text { petugas } \\
\text { kesehatan } \\
\text { sangat baik } \\
\text { - Tn.Z tetap } \\
\text { mengikuti } \\
\text { program } \\
\text { pengobatan }\end{array}$ & $\begin{array}{l}\text { Harga Diri Rendah } \\
\text { situasional }\end{array}$ \\
\hline
\end{tabular}




\section{Pohon Masalah}

TB Paru

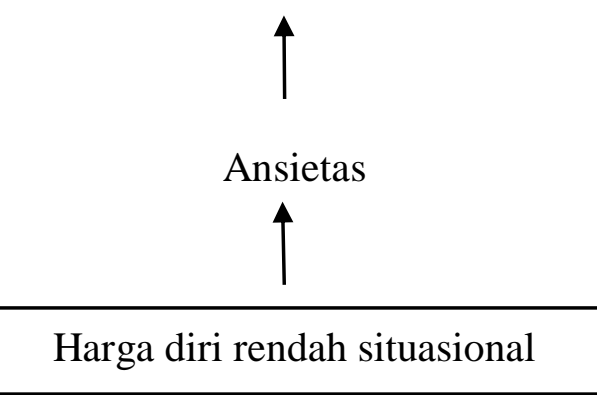

3.1.3 Sumber Koping

\begin{tabular}{|c|c|c|c|c|c|}
\hline $\begin{array}{c}\text { DIAGNOSA } \\
\text { KEPERAWATAN }\end{array}$ & $\begin{array}{l}\text { PERSONAL } \\
\text { ABILITY }\end{array}$ & SOSIAL SUPPORT & $\begin{array}{l}\text { MATERIAL } \\
\text { ASSETS }\end{array}$ & POSITIE BELIEFS & TERAPI \\
\hline $\begin{array}{l}\text { Harga Diri Rendah } \\
\text { situasiona }\end{array}$ & \begin{tabular}{|lr|}
\multicolumn{2}{|c}{ Tn. Z mengatakan } \\
bahwa r merasa \\
malu jika & keluar \\
rumah & dan \\
bertumu & dengan \\
orang lain, & T.Z \\
berusaha & untuk \\
melakukan & \\
kegiatan & kecil
\end{tabular} & $\begin{array}{l}\text { - } \text { Tn.Z mendapatkan } \\
\text { dukungan dari pihak } \\
\text { keluarga untuk } \\
\text { kesembuhanya } \\
\text { - Ayah dan adik nya } \\
\text { bergantian merawat } \\
\text { klien }\end{array}$ & $\begin{array}{l}\text { - } \text { Tn.Z } \\
\text { mengatakan } \\
\text { dana yang } \\
\text { digunakan untuk } \\
\text { berobat } \\
\text { menggunakan } \\
\text { dana pribadi }\end{array}$ & 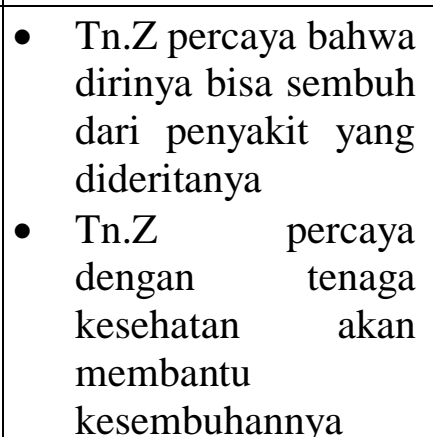 & $\begin{array}{ll}\text { 1. } & \text { Terapi supportif } \\
\text { 2. } & \text { Kognitif terapi } \\
\text { 3. } & \text { Family } \\
& \text { psikoedukasi }\end{array}$ \\
\hline
\end{tabular}




\begin{tabular}{|c|c|c|c|c|c|}
\hline & $\begin{array}{l}\text { untuk } \\
\text { mengalihkan } \\
\text { pikiran dengan } \\
\text { cara menonton } \\
\text { televesi } \\
\text { - Tn.Z mengatakan }\end{array}$ & & & $\begin{array}{ll}\text { - } & \text { Selalu berdoa } \\
& \text { kepada allah SWT }\end{array}$ & \\
\hline Kurang Pengetahuan & $\begin{array}{l}\text { - Tn. Z mampu } \\
\text { mengenal dan } \\
\text { menilai keadaan } \\
\text { dari penyakitnya } \\
\text { - Tn.Z mampu } \\
\text { melatih cara hidup } \\
\text { sehat }\end{array}$ & $\begin{array}{l}\text { - Tn .Z mendapat } \\
\text { dukungan dari } \\
\text { keluarga untuk } \\
\text { kesembuhannya } \\
\text { - Keluarga Tn.Z } \\
\text { bergantian } \\
\text { menjaga }\end{array}$ & $\begin{array}{l}\text { - Sosial ekonomi } \\
\text { Tn.Z menengah } \\
\text { Pengobatan } \\
\text { ditanggung } \\
\text { BPJS } \\
\text { - Jarak rumah } \\
\text { Tn.Z dengan } \\
\text { tempat } \\
\text { pelayanan } \\
\text { kesehatan lebih } \\
\text { kurang } 3 \mathrm{Km}\end{array}$ & $\begin{array}{l}\text { - Tn.Z percaya } \\
\text { bahwa petugas } \\
\text { kesehatan akan } \\
\text { membantunya } \\
\text { - Tn.Z berharap } \\
\text { cepat sembuh } \\
\text { agar tidak } \\
\text { merepotkan }\end{array}$ & $\begin{array}{l}\text { Terapi generalis: } \\
\text { - SP 1-2 kurang } \\
\text { pengetahuan } \\
\text { - Terapi spesialis: } \\
\text { - Terapi suportif, } \\
\text { FPE }\end{array}$ \\
\hline Ansietas & $\begin{array}{l}\text { - Tn.Z dapat } \\
\text { mengungkapkan } \\
\text { perasaan sedih } \\
\text { dan khawatirnya } \\
\text { - Tn.Z mampu } \\
\text { menghilangkan } \\
\text { khawatir dan } \\
\text { cemas dengan }\end{array}$ & $\begin{array}{l}\text { - } \text { Tn.Z mendapatkan } \\
\text { dukungan dari pihak } \\
\text { keluarga } \\
\text { kesembuhanya } \\
\text { Ayah dan adik nya } \\
\text { bergantian merawat } \\
\text { klien }\end{array}$ & $\begin{array}{l}\text { - Tn.Z } \\
\text { mengatakan } \\
\text { dana yang } \\
\text { digunakan untuk } \\
\text { berobat } \\
\text { menggunakan } \\
\text { dana pribadi }\end{array}$ & 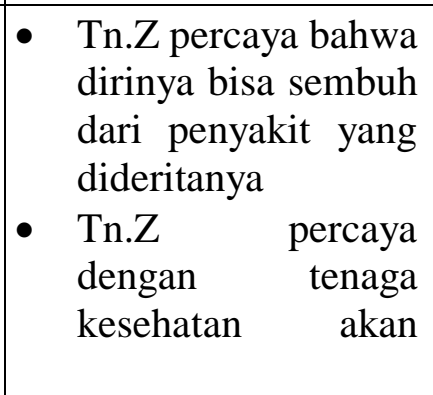 & $\begin{array}{ll}\text { Terapi spesialis: } \\
\text { - } & \text { Relaksasi } \\
& \text { progresif } \\
\text { - } & \text { Psikoedukasi } \\
& \text { keluarga } \\
\text { - } & \text { Behavior } \\
& \text { therapy }\end{array}$ \\
\hline
\end{tabular}




\begin{tabular}{|l|l|l|l|l|}
\hline & $\begin{array}{l}\text { mengalihkan } \\
\text { pikiran seperti } \\
\text { menonton tv atau } \\
\text { berbicara dengan } \\
\text { adiknya }\end{array}$ & & $\begin{array}{l}\text { membantu } \\
\text { kesembuhannya } \\
\text { berdoa } \\
\text { kepada allah SWT }\end{array}$ \\
\hline
\end{tabular}

\subsubsection{Mekanisme Koping}

\begin{tabular}{|c|c|}
\hline HAL YANG DILAKUKAN & ANALISA \\
\hline $\begin{array}{l}\text { - } \\
\text { - Tn. Z taat dalam beribadah } \\
\text { penyakit yang dideritanya saat ini } \\
\text { - Tn.Z mengatakan jika penyakitnya kambuh maka dia akan } \\
\text { kerumah sakit } \\
\text { - Tn. Z mengatakan jika ada masalah, klien akan } \\
\text { mebicarakannya dengan keluarga terutama kepada ayahnya }\end{array}$ & $\begin{array}{l}\text { Konstruktif } \\
\text { Tn. Z taat dalam beribadah } \\
\text { Tn.Z selalu berdoa kapada allah SWT untuk kesembuhan } \\
\text { penyakit yang dideritanya saat ini } \\
\text { Tn.Z mengatakan jika penyakitnya kambuh maka dia } \\
\text { akan kerumah sakit } \\
\text { Tn.Z mengatakan jika ada masalah, klien akan } \\
\text { mebicarakannya dengan keluarga terutama kepada } \\
\text { ayahnya dan mencari solusi yang tepat } \\
\text { - Destruktif :- }\end{array}$ \\
\hline
\end{tabular}




\subsubsection{Status Mental}

\begin{tabular}{|l|l|}
\hline 1. Penampilan & Bersih, rapi, tidak tercium bau, Tn .Z tampak lemas \\
\hline 2. Pembicaraan & Tn .Z menunjukkan bahwa klien cenderung murung dan pasif \\
\hline 3. Aktivitas motoric & Tn .Z mengatakan tubuh terasa lemas dan sulit bergerak \\
\hline 4. Interaksi selama wawancara & Cukup kooperatif, meskipun pasif \\
\hline 5. Alam perasaan & $\begin{array}{l}\text { merasa sedih, malu karena menjadi tidak produktif dan merasa khawatir akan masa } \\
\text { depannya kelak }\end{array}$ \\
\hline 6. Afek & Datar \\
\hline 7. Persepsi & Tn .Z mengalami gangguan dalam proses sensori-persepsi \\
\hline 8. Isi piker & Mengalami masalah karena sebagian memori terlupakan \\
\hline 9. Proses piker & masalah karena sebagian memori terlupakan \\
\hline 10. Tingkat kesadaran & Tn.Z dapat menyebutkan kembali semua nama anggota keluarganya \\
\hline 11. Daya ingat & Tn.Z tidak dapat mengingat beberapa kejadian dalam hidupnya \\
\hline 12. Kemampuan berhitung & Kemampuan berhitung cukup baik \\
\hline 13. Penilaian & Tn.Z belum mampu menyebutkan bagaimana caranya agar klien lekas sembuh \\
\hline 14. Daya tilik diri & $\begin{array}{l}\text { Tn .Z menyadari bahwa saat ini ia sadang sakit, Tn. Z hanya bisa berdoa supaya lekas } \\
\text { sembuh agar tidak terus merepotkan keluarganya terutama ayahnya. Tn. } Z \text { menyadari } \\
\text { ia memiliki keluarga yang menyayanginya dan mendukung kesembuhannya }\end{array}$ \\
\hline
\end{tabular}

Kesimpulan : Mental Status Examination (MSE) tidak ada masalah gangguan jiwa, gangguan Tn.Z lebih kepada Gangguan Mental Emosional (GME/Psikososial) 


\subsection{Diagnosa Dan Terapi}

DIAGNOSA KEPERAWATAN DAN TERAPI KEPERAWATAN

DIAGNOSA MEDIS

1. Harga Diri Rendah Situasiona

Sp1 : Klien dapat mengidentifisi aspek positif dan kemampuan yang dimiliki

Sp2 : Menilai kemampuan yang dapat digunakan

Sp3 : Menetapkan atau memilih kegiatan sesuai kemampuan

Sp4 : Melatih kegiatan sesuai kemampuan yang dipilih

2. Ansietas

Sp1: mendiskusikan penyebab,terjadinya prosesterjadi, tanda gejala,akibat

Sp2 :melatih teknik releksasi fisik

Sp3:melatih mengatasi ansietas dengan distraksi dan hipnotis lima

Sp4 : melatih mengatasi ansietas memalui kegiatan spiritual

3. Kurang pengetahuan

Terapi suportif, FPE

\subsection{Implementasi Tindakan Keperawatan Dan Evaluasi}

\begin{tabular}{|l|l|}
\hline IMPLEMENTASI TINDAKAN KPERAWATAN & EVALUASI \\
\hline Tanggal $: 09$ Oktober 2021 & $\mathbf{S}:$ Senang \\
Jam $: 10.00-15.00$ wib & $\mathbf{O}:$ \\
1. Menenangkan pasien & \\
\hline
\end{tabular}


2. Memahami keadaan pasien

3. Mendiskusikan penyebab,terjadinya prosest terjadi, tanda gejala dan akibat

4. Mengidentifikasi aspek positif yang dimiliki pasien yaitu berdoa dan bersyukur.

5. Menilai kemampuan yang dapat digunakan

6. Menetapkan atau memilih kegiatan sesuai kemampuan
- Klien mampu Mengidentifikasi aspek positif yang dimiliki dengan motivasi

- Klien mampu memilih dan menetapkan kegiatan sesuai kemampuan

A : Harga Diri Rendah Situasional (+)

P :

- Latihan mengindentifikasi kemampuan dan aspek positif yang dimiliki 3x/hari

\section{S : Senang}

O :

- Klien mampu melakukan kegiatan sesuai kemampuan

- Klien mampu melatih kegiatan sesuai kemampuan yaitu membersihkan rumah

A : Harga Diri Rendah Situasional (+)

P :

- Latihan mengindentifikasi kemampuan dan aspek positif yang dimiliki $3 \mathrm{x} / \mathrm{hari}$

- Latihan kegiatan yang dipilih seperti menyapu halaman

Tanggal : 12 Oktober 2021

S : Senang

Jam : $14.00-16.00$ wib

1. Melatih kegiatan sesuai kemampuan yang dipilih 3
O : klien mampu melakukan kegiatan sesuai kemampuan yang dipilih

A : Harga diri rendah Situasional (-)

P : 


\begin{tabular}{|c|c|}
\hline & $\begin{array}{l}\text { - Latihan mengidentifikasi kemampuan dan aspek positif } \\
\text { yang dimiliki } 3 x / \text { hari } \\
\text { - Latihan kegiatan yang di pilih } 3 \text { seperti melukis / } \\
\text { menggambar }\end{array}$ \\
\hline $\begin{array}{l}\text { Tanggal : } 13 \text { Oktober } 2021 \\
\text { Jam : } 11.00 \text { - } 14.00 \text { wib } \\
\text { 1.Menenangkan pasien } \\
\text { 2.Memahami keadaan pasien } \\
\text { 3.Mendiskusikan penyebab, proses terjadinya, tanda gejala,akibat } \\
\text { 4.Mengkaji tingkat ansietas } \\
\text { 5.Melatih pasien teknik relaksasi tarik nafas dalam } \\
\text { 6.Melatih pasien mengatasi ansietas dengan ditraksi dan hipnotis } \\
\text { lima jari } \\
\text { 7.Mengkaji kegiatan spritual pasien } \\
\text { 8.Mendukung keterlibatan keluarga dengan cara yang tepat }\end{array}$ & 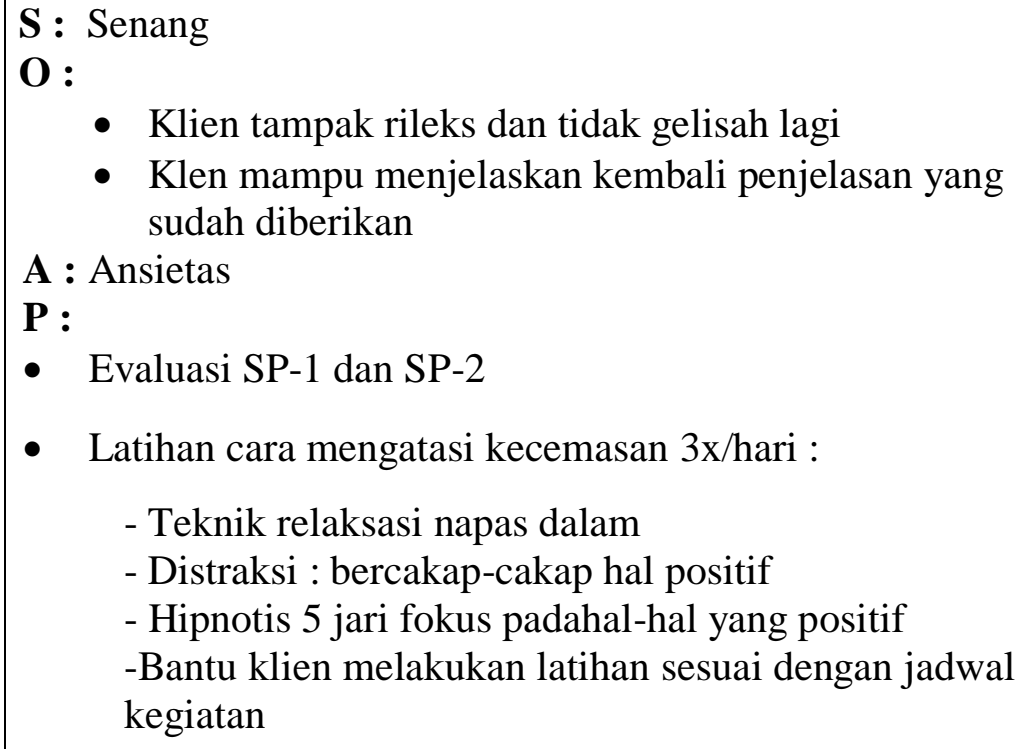 \\
\hline $\begin{array}{l}\text { Tanggal : } 14 \text { Oktober } 2021 \\
\text { Jam : } 10.00 \text { wib } \\
\text { a. Latihan cara mengatasi kecemasan : } \\
\text { - Teknik relaksasi napas dalam } \\
\text { - Distraksi : bercakap-cakap hal positif } \\
\text { - Hipnotis } 5 \text { jari fokus padahal-hal yang positif } \\
\text { b. Bantu klien melakukan latihan sesuai dengan jadwal kegiatan. }\end{array}$ & $\begin{array}{l}\text { S : Senang dan antusias } \\
\text { O : } \\
\text { - Klien tampak rileks dan tidak gelisah lagi } \\
\text { - Klen mampu menjelaskan kembali penjelasan yang } \\
\\
\text { - } \text { sudah diberikan } \\
\text { - Klien mampu melakukan teknik napas dalam } \\
\text { - Klien mampu melakukan distraksi } \\
\text { A : Ansietas } \\
\mathbf{P}:\end{array}$ \\
\hline
\end{tabular}




\begin{tabular}{|l|l|}
\hline & $\begin{array}{l}\text { Bantu klien melakukan latihan sesuai dengan jadwal } \\
\text { kegiatan 3x/hari }\end{array}$ \\
& $\begin{array}{l}\text { - Terapi Perilaku } \\
\text { - Terapi Kognitif } \\
\text { - Pendidikan Kesehatan }\end{array}$ \\
\hline
\end{tabular}




\section{BAB 4}

\section{PEMBAHASAN}

Setelah penulis melaksanakan asuhan keperawatan kepada Tn. Z dengan Harga Diri Rendah Situasional di wilaya tembung pasar 7 maka penulis pada BAB ini akan membahasan kesenjangan antara teoritis dengan tinjauan kasus. Pembahasan dimulai melalui tahapan proses keperawatan yaitu pengkajian, diagnosa keperawatan, perencanaan, pelaksanaan dan evaluasi.

\section{A. Tahap Pengkajian}

Selama pengkajian dilakukan pengumpulan data dari beberapa sumber, yaitu dari pasien dan keluarga. Maka penulis melakukan pendekatan kepada pasien melalui komunikasi teraupetik yang lebih terbuka membantu klien untuk memecahkan perasaannya dan juga melakukan observasi kepada pasien. Adapun upaya tersebut yaitu :

a. Melakukan pendekatan dan membina hubungan saling percaya diri pada klien agar klien lebih terbuka dan lebih percaya dengan menggunakan perasaan.

b. Mengadakan pengkajian klien dengan wawancara Dalam pengkajian ini, penulis tidak menemukan kesenjangan karena ditemukan hal sama seperti: diteori: Harga Diri Rendah Situasional adalah suatu kegagalan dalam menjalankan fungsi dan peran yang terjadi secara tiba-tiba misalnya terkenak penyakit, harus putus sekolah, putus hubungan kerja, perasaan malu terhadap diri sendiri karena sesuatu

\section{B. Diagnosa Keperawatan}

Diagnosis keperawatan ialah identifikasi atau penilaian terhadap pola respons klien baik actual maupun potensial dan merupakan dasar pemilihan intervensi dalam mencapai tujuan yang telah di tetapkan oleh perawat yang bertanggung jawab. Datadata yang mendukung analisa data menurut (Keliat, 2015) :

1. Harga Diri Rendah Situasional

2. Ansietas

3. Kurang Pengetahuan 


\section{A. Tahap Perencanaan}

Perencanaan dalam proses keperawatan lebih di kenal dengan asuhan keperawatan yang merupakan tahap selanjutnya setelah pengkajian dan penentuan diagnosa keperawatan. Pada tahap perencanaan mahasiswa hanya menyusun rencan tindakan keperawatan ketidak berdayaan. Pada tahap ini antara tinjauan teoritis dan tinjauan kasus tidak ada kesenjangan sehingga mahasiswa dapat melaksanakan tindakan seoptimal mungkin di dukung dengan seringnya bimbingan dengan pembimbing. Secara teoritis digunakan secara strategi pertemuan sesuai dengan diagnosa keperawatan yang muncul saat pengkajian. Adapun upaya yang digunakan mahasiswa ialah :

1. Harga diri rendah situasional

- Mengidentifikasi penyebab, tanda dan gejala, proses terjadinya dan akibat harga diri rendah situasional

- Mengidentifikasi kemampuan dan aspek positif yang dimiliki

- Menilai kemampuan yang dapat digunakan

- Menetapkan/memilih kegiatan sesuai kemampuan

- Melatih kegiatan yang sudah dipilih sesuai kemampuan

- Melakukan kegiatan yang sudah dilatih

2. Ansietas

Sp1: mendiskusikan penyebab,terjadinya prosesterjadi, tanda gejala,akibat

$\mathrm{Sp} 2$ :melatih teknik releksasi fisik

Sp3:melatih mengatasi ansietas dengan distraksi dan hipnotis lima

Sp4 : melatih mengatasi ansietas memalui kegiatan spiritual

3. Kurang pengetahuan

Terapi suportif, FPE 


\section{B. Tahap Implementasi}

1. Harga diri rendah situasional

- Mengidentifikasi penyebab, tanda dan gejala, proses terjadinya dan akibat harga diri rendah situasional

- Mengidentifikasi kemampuan dan aspek positif yang dimiliki

- Mendiskusikan bahwa sejumlah kemampuan dan aspek positif yang dimiliki pasien seperti kegiatan pasien dirumah, dalam keluarga dan lingkungan adanya keluarga dan lingkungan terdekat klien

- Beri pujian yang realistik/nyata dan hindarkan setiap kali bertemu dengan pasien penilian yang negatif

- Menilai kemampuan yang dapat digunakan

- Mendiskusikan pasien kemampuan yang masih dapat digunkaan saat ini

- Bantu pasien menyebutkan dan memberi penguatan terhadap kemampuan diri yang diungkapkan pasien

- Perlihatkan respon yang kondusif dan pendengar yang aktif

- Menetapkan/memilih kegiatan sesuai kemampuan

- Mendiskusikan dengan pasien beberapa kegiatan yang dapat dilakukan dan dipilih sebagai kegiatan yang akan pasien lakukan sehari-hari

- Bantu pasien menetapkan kegiatan mana yang dapat pasien lakukan secara mandiri dan minimal. Berikan contoh cara pelaksanaan kegiatan yang dapat dilakukan pasien, susun daftar kegiatan sehari-hari pasien.

- Melatih kegiatan yang sudah dipilih sesuai kemampuan

- Melatih kegiatan yang sudah dilatih

Pada diagnosa keperawatan harga diri rendah strategi pertemuan ialah mengidentifikasi masalah, mengidentifikasi aspek positif yang dimiliki, ajarkan terapi supportive, Cognitive Therapy (CT), dan family psychoedication (FPE).

\section{Tahap Evaluasi}

Pada tinjauan kasus evaluasi yang dihasilkan adalah :

1. Harga diri rendah situasional 
- Klien sudah dapat mengidentifikasi penyebab, tanda dan gejala, proses terjadinya dan akibat harga diri rendah situasional

- Klien sudah dapat melakukan kemampuan dan aspek positif yang dimiliki

- Klien sudah dapat menilai kemampuan yang dapat digunakan

- Klien sudah dapat menetapkan/memilih kegiatan sesuai kemampuan

- Klien sudah dapat melatih kegiatan yang sudah dipilih sesuai kemampuan

- Klien sudah dapat melakukan kegiatan yang sudah dilatih

2. Ansieatas

- Klien mengatakan : merasa lebih tenang dan tidak merasa cemas lagi

- Klien mengatakan ia mampu mengindentifikasi situasi yang mencetus ansietas

- Klien mengatakan sudah bisa melakukan teknik tarik napas dalam

- Klien mengatakan sudah bisa melakukan teknik distraksi

- Klien mengatakan sudah bisa melakukan teknik hipnotis 5 jari 


\section{BAB 5}

\section{PENUTUP}

\subsection{Kesimpulan}

Berdasarkan konsep asuhan keperawatan yang telah disusun dan dilaksanakan kepada Tn.Z dimiliki dari pengkajian, rumusan masalah, perencanaan, pelaksanaan hingga evaluasi didapat hasil bahwa Tn.Z dengan keluhan utama malu akan Penyakit Tb paru yang di deritanya dan malu karena menjadi tidak produktif lagi. Objektif yaitu klien tampak Badan lemas, Batuk, dan terkadang menunduk. Dari masalah masalah diatas maka diperoleh prioritas masalah yang diangkat adalah tentang Harga Diri Rendah Situasional. Kemudian diberikan intervensi secara konsep yaitu melatih kegiatan yang dipilih. Dari hasil implementasi ada beberapa intervensi yang berhasil teratasi seperti klien sudah mulai mau untuk megatakan penyakitnya yang sebenarnya, klien mampu membuka diri pada keluarga, Tetapi kelien masih sedikit malu oleh rekan-rekannya yang berkerja dulu.

\subsection{Saran}

Diharapkan bagi perawat selalu berkoordinasi dengan tenaga kesehatan lainnya dalam memberikan asuhan keperawatan agar lebih maksimal terkusus pada klien dengan Harga Diri Rendah Situasional pada pasien Tb Paru. 


\section{DAFTAR PUSTAKA}

1. Depkes. (2019). Pedoman nasional penanggulangan tuberkulosis, Edisi 2. Jakarta.

2. Kenedyanti, E., \& Sulistyorini, L. (2017). Analisis Mycobacterium Tuberkulosis Dan Kondisi Fisik Rumah dengan Kejadian Tuberkulosis Paru. Jurnal Berkala Epidemiologi, 5(2), 152-162. https://doi.org/10.20473/jbe.v5i2.2017.152-162

3. Kemenkes RI. (2018). Riset Kesehatan Dasar, RISKESDAS.Jakarta: Kemenkes RI.

4. Kemenkes RI. (2020). Riset Kesehatan Dasar, RISKESDAS.Jakarta: Kemenkes RI.

5. Kholifah, Nurul, S.,\& Indreswari, S.A. (2015). Faktor Terjadinya Tuberkulosis Paru pada Anak Berdasarkan Riwayat Kontak Serumah Vol 14, Nomor 2. Semarang: Jurnal Kesehatan Masyarakat. Fakultas Kesehatan Universitas Dian Nuswantoro. Di akses dari https://publikasi.dinus.ac.id/index.ph p/visikes/article/view/1203.

6. Noviyani, E., Fatimah, S., Nurhidayah, I., \& Adistie, F. (2015). Upaya Pencegahan Penularan TB dari Dewasa terhadap Anak, Vol 3 Nomor 2. Bandung:Jurnal Keperawatan Padjajaran Fakultas Keperawatan Universitas Padjadjaran. Di Akses dari jkp.fkep.unpad.ac.id.

7. Pardede, J. A., Keliat, B. A., \& Yulia, I. (2015). Kepatuhan Dan Komitmen Klien Skizofrenia Meningkat Setelah Diberikan Acceptance And Commitment Therapy Dan Pendidikan Kesehatan Kepatuhan Minum Obat. Jurnal Keperawatan Indonesia, 18(3), 157-166. Http://Jki.Ui.Ac.Id/Index.Php/Jki/Article/View/419

8. Pardede, J. A., Hafizuddin, H., \& Sirait, A. (2021). Coping Strategies Related to Self-Esteem on PLWHA in Medan Plus Foundation. Jurnal Ilmu Keperawatan Jiwa, 4(2), 255-262.

9. Pardede, J. A., Harjuliska, H., \& Ramadia, A. (2021). Self-Efficacy dan Peran Keluarga Berhubungan dengan Frekuensi Kekambuhan Pasien Skizofrenia. Jurnal Ilmu Keperawatan Jiwa, 4(1), 57-66. http://dx.doi.org/10.32584/jikj.v4i1.846

10. Pardede, J. A., Hutajulu, J., \& Pasaribu, P. E. (2020). Harga Diri dengan Depresi Pasien Hiv/aids. Jurnal Media Keperawatan: Politeknik Kesehatan Makassar, 11(01). https://doi.org/10.32382/jmk.v11i1.1538

11. Pardede, J. A., Simamora, M., \& Simanjuntak, G. V. (2020). Family 
Support and Self-Esteem of Patient with Breast Cancer Education, 25(6), 73-5.https://www.easpubliher.com/easjnm

12. Samosir, E. F. (2020). Penerapan Asuhan Keperawatan Jiwa Pada An . A Dengan Gangguan Konsep Diri : Harga Diri Rendah Di Lingk . XVI Lorong Jaya. 1-41.

13. Suprapto, S. (2018). Pengetahuan Dan Sikap Masyarakat Dalam Upaya Pencegahan Tuberkulosis Di Wilayah Kerja Puskesmas Batua Kota Makassar. Jurnal Ilmiah Kesehatan Sandi Husada, 1114-1124. https://doi.org/10.35816/jiskh.v6i1.10

14. Suryani, U., \& Efendi, Z. (2020). Dukungan Keluarga Berhubungan dengan Harga Diri pada Penderita Tuberkulosis Paru. Jurnal Ilmu Keperawatan Jiwa, 3(1), 53. https://doi.org/10.32584/jikj.v3i1.474

15. Turgut, M., Akhaddar, A., Turgut, A., \& Grag, R. (2017). Tuberculosis of The Central Nervous System. In Postgraduate Medical Journal. Springer. https://doi.org/10.1136/pgmj.75.881.133

16. Lete, G. R., Kusuma, F. H. D., \& Rosdiana, Y. (2019). Hubungan Antara Harga Diri Dengan Resiliensi Remaja Di Panti Asuhan Bakti Luhur Malang. Nursing News: Jurnal Ilmiah Keperawatan, 4(1). Https://Publikasi.Unitri.Ac.Id/Index.Php/Fikes/Article/View/1436

17. Wandono, W. A., \& Arum Pratiwi, S. (2017). Upaya peningkatan harga diri rendah pada pasien depresi (Doctoral dissertation, Universitas Muhammadiyah Surakarta). http://eprints.ums.ac.id/id/eprint/52383

18. Widhaswari, D. O. (2017). Asuhan keperawatan psikososial harga diri rendah situasional pada klien dengan diabetes mellitus dan luka gangren di Ruang Antasena RS DR. H. Marzoeki Mahdi Bogor

19. Wilkinson, J.M., \& Ahern, N. R. (2009). Buku saku diagnosis keperawatan. Edisi 9. Jakarta: EGC.

20. Pardede, J. A., Huda, A., Saragih, M., \& Simamora, M. (2021). Verbals Bullying Related To Self-Esteem On Adolescents. Jendela Nursing Journal (JNJ), 5(1), 1622. https://doi.org/10.31983/jnj.v5i1.6903

21. Pardede, J. A. (2017). The Implementation of Family Tasks with The Frequency of Recurrence of Social Isolation Patients. Mental Health, 4(2).

22. Wijayati, F., Nasir, T., Hadi, I., \& Akhmad, A. (2020). Faktor-Faktor yang Berhubungan dengan Kejadian Harga Diri Rendah Pasien Gangguan Jiwa. Health Information: Jurnal Penelitian, 12(2), 224-235 https://doi.org/10.36990/hijp.v12i2.234 